\title{
Evaluation of the Hydrolab HL4 Water-Quality Sonde and Sensors
}

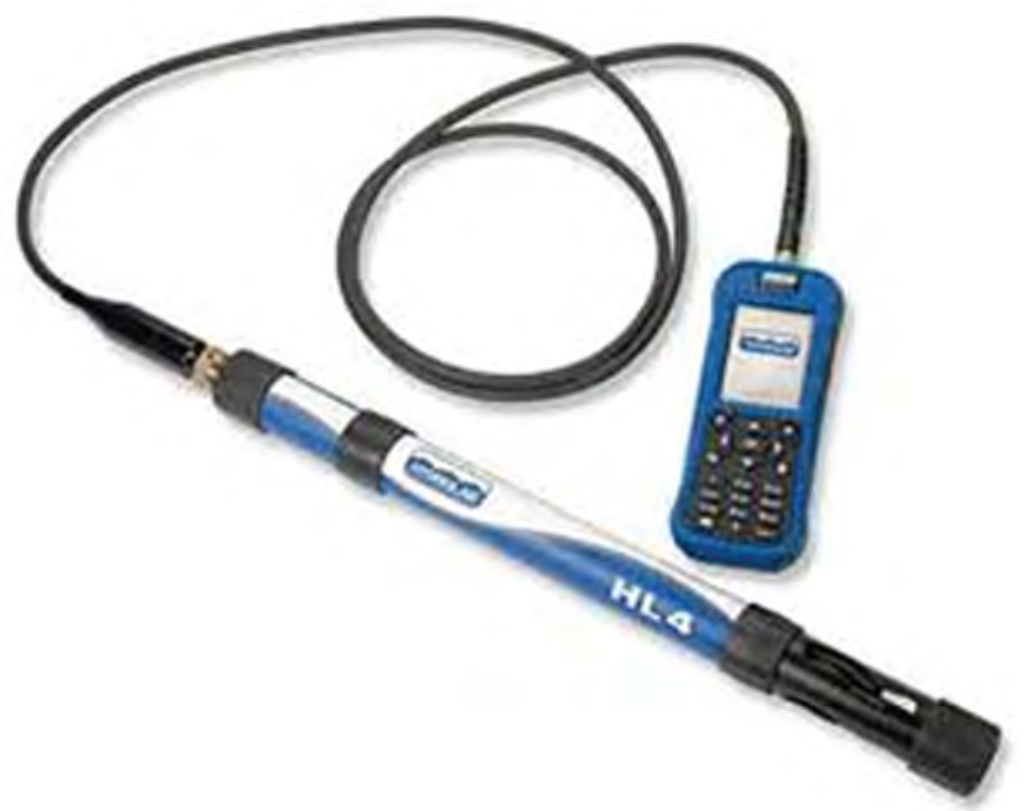

Open-File Report 2017-1153 
Cover. Photograph of Hydrolab HL4 multiparameter sonde and a Surveyor HL handheld manufactured by OTT Hydromet. (Image courtesy of OTT Hydromet, used with permission.) 


\section{Evaluation of the Hydrolab HL4 Water-Quality Sonde and Sensors}

By Teri T. Snazelle

Open-File Report 2017-1153

U.S. Department of the Interior

U.S. Geological Survey 


\title{
U.S. Department of the Interior \\ RYAN K. ZINKE, Secretary
}

\section{U.S. Geological Survey William H. Werkheiser, Deputy Director exercising the authority of the Director}

\author{
U.S. Geological Survey, Reston, Virginia: 2017
}

For more information on the USGS - the Federal source for science about the Earth, its natural and living resources, natural hazards, and the environment-visit https://www.usgs.gov or call 1-888-ASK-USGS.

For an overview of USGS information products, including maps, imagery, and publications, visit https://store.usgs.gov.

Any use of trade, firm, or product names is for descriptive purposes only and does not imply endorsement by the U.S. Government.

Although this information product, for the most part, is in the public domain, it also may contain copyrighted materials as noted in the text. Permission to reproduce copyrighted items must be secured from the copyright owner.

Suggested citation:

Snazelle, T.T., 2017, Evaluation of the Hydrolab HL4 water-quality sonde and sensors: U.S. Geological Survey OpenFile Report 2017-1153, 20 p., https://doi.org/10.3133/ofr20171153.

ISSN 2331-1258 (online) 


\section{Contents}

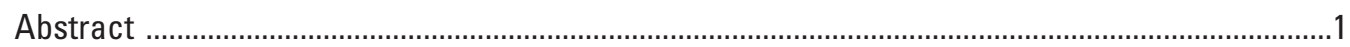

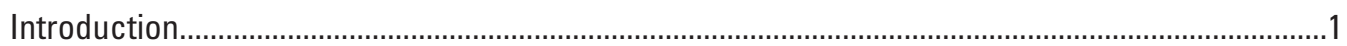

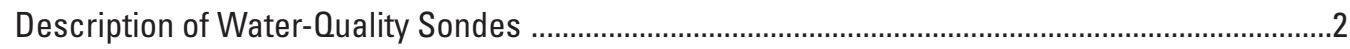

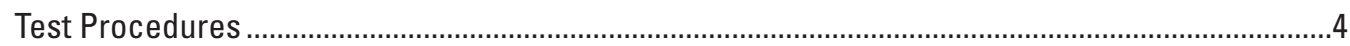

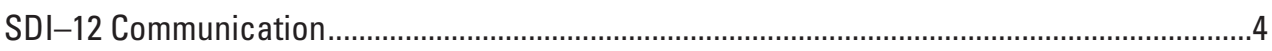

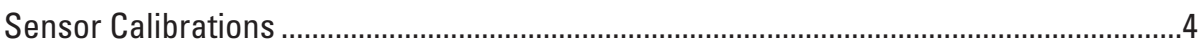

Laboratory Testing of the HL4

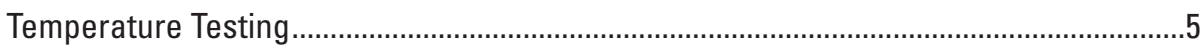

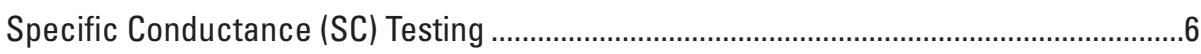

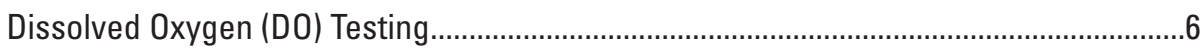

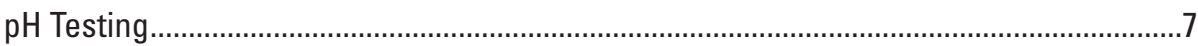

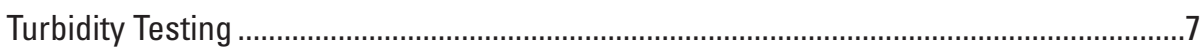

Field Testing of the HL4 ….................................................................................................

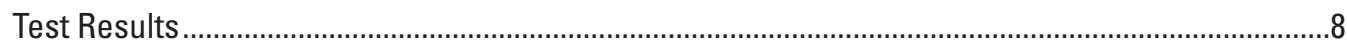

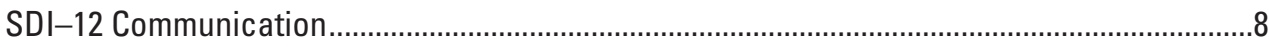

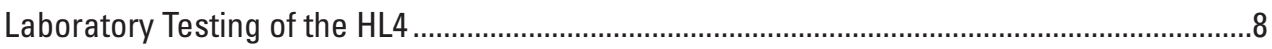

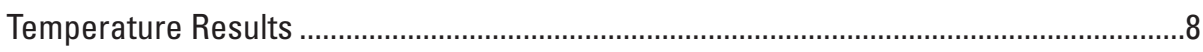

Specific Conductance Results ............................................................................. 10

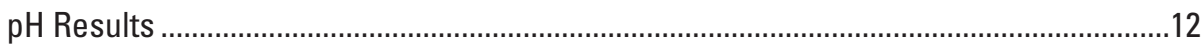

Dissolved Oxygen (DO) Results ..........................................................................

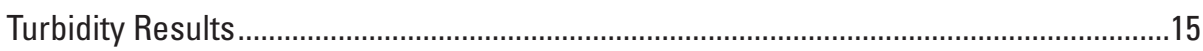

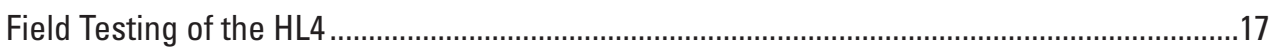

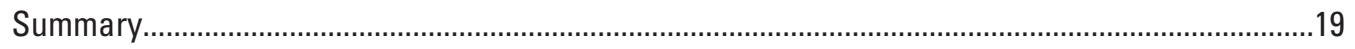

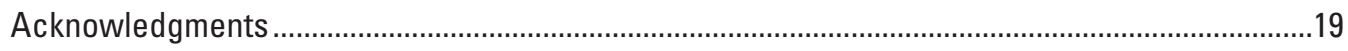

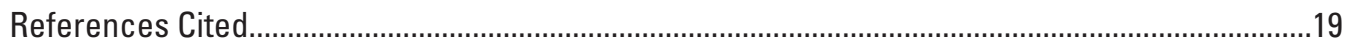

\section{Figures}

1. Photograph showing a Hydrolab HL4 multiparameter sonde and a Surveyor HL handheld manufactured by OTT Hydromet...................................................................

2. Photographs of HL4 sonde with warped sensor guard after the initial ramped temperature test

3. Plot showing the percent difference for three HL4 sensors between the measured specific conductance and the standard values at room temperature ............................10

4. Plots showing the percent difference for three HL4 sensors between the measured specific conductance values and standard values in 100- and 10,000-microsiemensper-centimeter standards at $5,15,25$, and $40^{\circ} \mathrm{C}$

5. Plot showing the difference in measured and standard $\mathrm{pH}$ from three Hydrolab HL4 sondes in $1.68,3.01,4.00,5.00,6.86,7.00,9.18,10.03$, and $12.45 \mathrm{pH}$ standards at room temperature...

6. Plots showing results from the testing of $\mathrm{pH}$ in 5.00 and $9.18 \mathrm{pH}$ standards at 5 , 15, 25, and 40 degrees Celsius. 
7. Plot showing the differences between the measured dissolved oxygen concentrations from three Hydrolab HL4 sondes and the dissolved oxygen concentrations from Standard Methods 4500-0 C Winkler titrations at 0, 2.10, 8.20, and $12.80 \mathrm{mg} / \mathrm{L}$.

8. Plot showing the differences between the measured dissolved oxygen concentrations from three Hydrolab HL4 sondes and the calculated theoretical dissolved oxygen at $0,2.14,8.26$, and $13.11 \mathrm{mg} / \mathrm{L}$

9. Plot showing the percent difference between the measured turbidity from three Hydrolab HL4 sondes and the StabICal standard turbidity values, in nephelometric turbidity units

10. Hydrographs showing temperature, specific conductance, $\mathrm{pH}$, dissolved oxygen, and turbidity field data from the Hydrolab HL4 and EXO2 sondes.

\section{Tables}

1. General manufacturer specifications for the base Hydrolab HL4 multiparameter sonde

2. Technical specifications for the tested Hydrolab HL4 turbidity sensors............................

3. Test criteria derived from the NFM (Gibs and others, 2007) and TM1-D3 ..........................

4. Test critieria for field deployment evaluation of the Hydrolab HL4 sensors. .....................8

5. Temperature statistical data from testing of three Hydrolab HL4 sondes .........................9

6. Summary of the field testing measurements by the EX02 site sonde and the Hydrolab HL4 sonde at USGS site 02492620, Pearl River at NSTL Station, Mississippi, June 21-July 21, 2016

\section{Conversion Factors}

U.S. customary units to International System of Units

\begin{tabular}{|c|c|c|}
\hline Multiply & By & To obtain \\
\hline \multicolumn{3}{|c|}{ Length } \\
\hline inch (in.) & 2.54 & centimeter $(\mathrm{cm})$ \\
\hline inch (in.) & 25.4 & millimeter (mm) \\
\hline foot (ft) & 3.28 & meter (m) \\
\hline \multicolumn{3}{|c|}{ Mass } \\
\hline pound, avoirdupois (lb) & 0.4536 & kilogram (kg) \\
\hline
\end{tabular}

International System of Units to U.S. customary units

\begin{tabular}{lcl}
\hline \multicolumn{1}{c}{ Multiply } & By & \multicolumn{1}{c}{ To obtain } \\
\hline centimeter $(\mathrm{cm})$ & Length & \\
meter $(\mathrm{m})$ & 0.3937 & inch (in.) \\
& 3.281 & foot (ft) \\
\hline kilogram $(\mathrm{kg})$ & Mass & \\
\hline
\end{tabular}


Temperature in degrees Celsius $\left({ }^{\circ} \mathrm{C}\right)$ may be converted to degrees Fahrenheit $\left({ }^{\circ} \mathrm{F}\right)$ as follows:

$$
{ }^{\circ} \mathrm{F}=\left(1.8 \times{ }^{\circ} \mathrm{C}\right)+32
$$

Temperature in degrees Fahrenheit $\left({ }^{\circ} \mathrm{F}\right)$ may be converted to degrees Celsius $\left({ }^{\circ} \mathrm{C}\right)$ as follows:

${ }^{\circ} \mathrm{C}=\left({ }^{\circ} \mathrm{F}-32\right) / 1.8$

Specific conductance is given in microsiemens per centimeter at 25 degrees Celsius $\left(\mu \mathrm{S} / \mathrm{cm}\right.$ at $\left.25^{\circ} \mathrm{C}\right)$.

Concentrations of chemical constituents in water are given in milligrams per liter (mg/L).

\section{Abbreviations}

$\begin{array}{ll}\text { BP } & \text { barometric pressure } \\ \text { DCP } & \text { data collection platform } \\ \text { DI } & \text { deionized water } \\ \text { DO } & \text { dissolved oxygen } \\ \text { FNU } & \text { formazin nephelometric units } \\ \text { GB } & \text { gigabyte } \\ \text { HIF } & \text { Hydrologic Instrumentation Facility (USGS) } \\ \text { M } \Omega & \text { megaohm } \\ \text { mmHg } & \text { millimeters of mercury } \\ \text { mW } & \text { milliwatts } \\ \text { NIST } & \text { National Institute of Standards and Technology } \\ \text { NTU } & \text { nephelometric turbidity units } \\ \text { PC } & \text { personal computer } \\ \text { SC } & \text { specific conductance } \\ \text { SDI } & \text { serial data interface } \\ \text { USB } & \text { universal serial bus } \\ \text { USGS } & \text { U.S. Geological Survey } \\ \text { VDC } & \text { volts of direct current } \\ \text { W } & \text { watts }\end{array}$





\title{
Evaluation of the Hydrolab HL4 Water-Quality Sonde and Sensors
}

\author{
By Teri T. Snazelle
}

\begin{abstract}
The U.S. Geological Survey (USGS) Hydrologic Instrumentation Facility evaluated three Hydrolab HL4 multiparameter water-quality sondes by OTT Hydromet. The sondes were equipped with temperature, conductivity, pH, dissolved oxygen (DO), and turbidity sensors. The sensors were evaluated for compliance with the USGS National Field Manual for the Collection of Water-Quality Data (NFM) criteria for continuous water-quality monitors and to verify the validity of the manufacturer's technical specifications. The conductivity sensors were evaluated for the accuracy of the specific conductance (SC) values (conductance at 25 degrees Celsius $\left[{ }^{\circ} \mathrm{C}\right]$ ), that were calculated by using the vendor default method, Hydrolab Fresh. The HL4's communication protocols and operating temperature range along with accuracy of the water-quality sensors were tested in a controlled laboratory setting May 1-19, 2016. To evaluate the sonde's performance in a surface-water field application, an HL4 equipped with temperature, conductivity, pH, DO, and turbidity sensors was deployed June 20-July 22, 2016, at USGS water-monitoring site 02492620, Pearl River at National Space Technology Laboratories (NSTL) Station, Mississippi, located near Bay Saint Louis, Mississippi, and compared to the adjacent well-maintained EXO2 site sonde.

The three HL4 sondes met the USGS temperature testing criteria and the manufacturer's technical specifications for temperature based upon the median room temperature difference between the measured and standard temperatures, but two of the three sondes exceeded the allowable difference criteria at the temperature extremes of approximately 5 and $40{ }^{\circ} \mathrm{C}$. Two sondes met the USGS criteria for SC. One of the sondes failed the criteria for SC when evaluated in a 100,000-microsiemensper-centimeter $(\mu \mathrm{S} / \mathrm{cm})$ standard at room temperature, and also failed in a $10,000-\mu \mathrm{S} / \mathrm{cm}$ standard at 5,15 , and $40^{\circ} \mathrm{C}$. All three sondes met the USGS criteria for $\mathrm{pH}$ and $\mathrm{DO}$ at room temperature, but one sonde exceeded the allowable difference criteria when tested in $\mathrm{pH} 5.00$ buffer and at $40{ }^{\circ} \mathrm{C}$. The USGS criteria and the technical specifications for turbidity were met by one sonde in standards ranging from 10 to 3,000 nephelometric turbidity units (NTU). A second sonde met the USGS criteria and the technical specifications except in the 3,000-NTU standard, and the third sonde exceeded the USGS calibration criteria in the 10and 20-NTU standards and the technical specifications in the 20-NTU standard.

Results of the field test showed acceptable performance and revealed that differences in data sample processing between sonde manufacturers may result in variances between the reported measurements when comparing one sonde to another. These variances in data would be more pronounced in dynamic site conditions. The lack of a wiper or other sensor-cleaning device on the DO sensor could prove problematic, and could limit the use of the HL4 to profiling applications or at sites with limited biofouling.
\end{abstract}

\section{Introduction}

The U.S. Geological Survey (USGS) Hydrologic Instrumentation Facility (HIF) evaluates the performance of instruments and equipment that are used to measure hydrologic data. Instrument and equipment evaluations are done primarily to determine if particular devices would be suitable for use by USGS personnel for hydrologic data collection, and are in no way an endorsement of the product by the HIF. Evaluation reports document the results obtained with the instrument model and firmware used at the time of testing, and may or may not represent results obtained from software updates and instrument model improvements that occur after the dates of testing. This report documents the laboratory and field evaluation of an OTT Hydromet water-quality sonde, the Hydrolab HL4, equipped with temperature, conductivity (for specific conductance [SC]), pH, dissolved oxygen (DO), and turbidity sensors.

The sondes and sensors were tested at the USGS HIF and at a USGS field site for compliance with the manufacturer's technical specifications and with USGS-recommended criteria for multi-parameter instruments as described in chapter 6.8 of the USGS National Field Manual for the Collection of Water-Quality Data (NFM) (Gibs and others, 2007) and Guidelines and Standard Procedures for Continuous Water-Quality Monitors: Station Operation, Record Computation, and Data Reporting (Wagner and others, 2006). Accuracy was determined in the laboratory by comparing the sensor's measured values to certified 
National Institute of Standards and Technology (NIST)-traceable references if available. The accuracy of the HL4 sensors in the field were evaluated by deploying an HL4 sonde at USGS water-monitoring site 02492620, Pearl River at NSTL Station, Mississippi, near Bay Saint Louis, Mississippi, and comparing the sonde performance to a well-maintained permanent site sonde and a field sonde. At the time of the test, the continuous water-quality-site sonde at site 02492620 was a XYLEM EXO2 equipped with temperature, conductivity, $\mathrm{pH}, \mathrm{DO}$, and turbidity sensors. The calibrated field sonde used to periodically verify the accuracy of the site sonde was a similiarly equipped YSI 6920 V2-2. Site sonde is the term used for the deployed sonde that provides continuous data, and field sonde is the term used for a clean and calibration-verified sonde used to evaluate the performance of the site sonde. In addition to accuracy, the HL4 serial data interface at 1,200-baud (SDI-12) communication protocol was tested for adherence to all version 1.3 SDI-12 commands and bus transactions including timing, break response, and extended SDI-12 commands to ensure the sensor could communicate properly through the SDI-12 protocol.

The findings in this report are based on the OTT Hydromet communication software, Hydrolab Operating Software, release 1.0.23.79, and sonde firmware version 1.6. Sensor firmware versions were the following: temperature, 1.1; conductivity, 1.12; $\mathrm{pH}, 1.5$; DO, 1.6; and turbidity, 1.6. After a brief description of the sonde model, the communication, laboratory, and field-test procedures and results are described.

\section{Description of Water-Quality Sondes}

The Hydrolab HL4 multiparameter sonde (fig. 1; table 1) is the latest generation of water-quality sondes produced by OTT Hydromet (a company of the Danaher Corporation). The HL4 sonde is designed with a rugged housing, dual O-ring seals, and is rated for 200-meter depths (OTT Hydromet, 2013a). The sondes have several communication protocols, including Universal Serial Bus (USB), RS-485, RS-232, and SDI-12. HL4s can be operated with a computer, the Surveyor HL handheld, or a data logger; however, the Hydrolab USB communications module is required for the personal computer (PC) interface, and the Hydrolab SDI-12 communications module is required to interface the sondes with a data collection platform (DCP) that uses SDI-12 communication. HL4 software, sensors, and cables are not interchangeable with the Hydrolab Datasonde series.

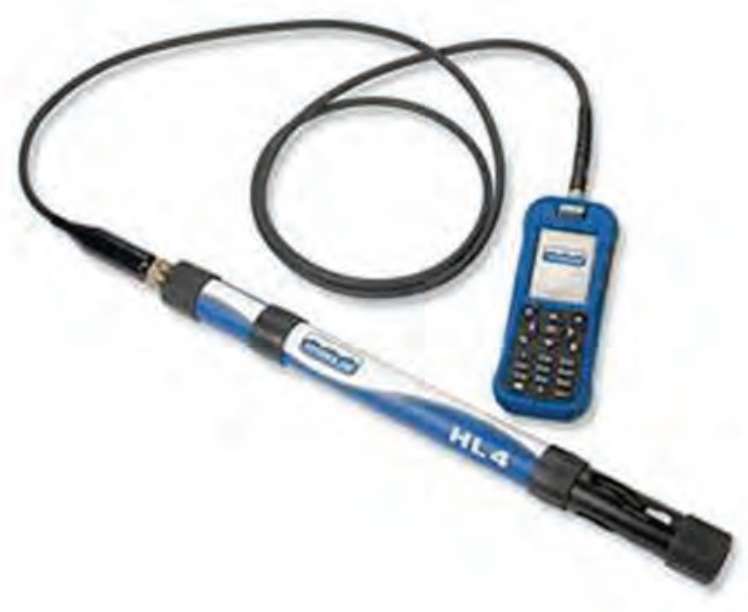

Figure 1. Hydrolab HL4 multiparameter sonde and a Surveyor HL handheld manufactured by OTT Hydromet. (Image courtesy of OTT Hydromet, used with permission.) 
Table 1. General manufacturer specifications for the base Hydrolab HL4 multiparameter sonde (OTT Hydromet, 2013a).

[cm, centimeter; in., inch; m, meter; ft, foot; GB, gigabyte; USB, universal serial bus; SDI, serial data interface; VDC, volts of direct current; mW, milliwatts; $\mathrm{W}$, watts; ${ }^{\circ} \mathrm{C}$, degrees Celsius; $\mathrm{kg}$, kilogram; lb, pound; TTY, Teletype]

\begin{tabular}{ll}
\hline \multicolumn{1}{c}{ Feature } & \multicolumn{1}{c}{ Specification } \\
\hline Material durability & Suitable for freshwater and saltwater \\
Diameter & $4.44 \mathrm{~cm}(1.75 \mathrm{in}$.) without rubber bumpers; $5.33 \mathrm{~cm}(2.1 \mathrm{in}$. $)$ with rubber bumpers \\
Length & $51.43 \mathrm{~cm}(20.25 \mathrm{in}$.$) no internal battery pack or sensor guard$ \\
& $62.23 \mathrm{~cm}(24.5 \mathrm{in}$.$) no internal battery pack, with extended sensor guard$ \\
& $62.23 \mathrm{~cm}(24.5 \mathrm{in}$.$) with internal battery pack and standard sensor guard$ \\
& $77.79 \mathrm{~cm}(30.63 \mathrm{in}$.$) with internal battery pack and extended sensor guard$ \\
Weight & $2.2 \mathrm{~kg}$ or $5 \mathrm{lb}$ \\
Power requirements & $6-24 \mathrm{VDC}, 12 \mathrm{VDC}$ \\
Power consumption & $250-\mathrm{mW}$ average, 18-W peak \\
Operating temperature & -5 to $50{ }^{\circ} \mathrm{C}$ \\
Operating depth & $200 \mathrm{~m}, 656 \mathrm{ft}$ of water \\
Logging & $4 \mathrm{~GB}$ internal memory \\
Communication protocols & $\mathrm{USB}, \mathrm{SDI}-12, \mathrm{RS}-232$, and RS-485 Modbus and RS-232 TTY \\
\hline
\end{tabular}

The Hydrolab HL4 communication software is the Hydrolab Operating Software. Its basic menu structure is

- Overview—the status of the sonde and sensors and any active alerts.

- Monitoring - provides real-time measurements in tabular and (or) graph format.

- Logging - provides the status of the last log made and a list of any completed logs kept on the instrument.

- Calibration-provides the date and type of the last calibration, the calibration interval, and the date of the next calibration, if applicable.

- Sensors-provides the sensor settings and information, including calibration information, if applicable.

- Settings - provides information on the general settings, firmware versions, security, and external dependencies.

The HL4 sensors are "fixed" sensors designed to be replaced in a controlled laboratory setting. The Hydrolab temperature sensor is a stainless steel variable resistance thermistor that is included with every Hydrolab sonde. The temperature sensor provides temperature compensation for $\mathrm{DO}, \mathrm{SC}, \mathrm{pH}$, depth, and other water-quality parameters. The conductivity sensor is a fourgraphite-electrode open-cell design that improves circulation and reduces interferences. The open-cell concept of this sensor is designed to reduce error associated with sediment and air bubbles. Hydrolab software offers several user-selectable options for temperature compensation for the calculation of SC. These options are Hydrolab Fresh (default), Hydrolab Salt, Standard Methods 2510, DIN EN 27888, and custom (OTT Hydromet, 2013c). The HL4 sondes in the evaluation were programmed to use the default setting (Hydrolab Fresh) for laboratory and field testing per vendor recommendation. The $\mathrm{pH}$ sensor in this evaluation uses an integrated glass-bulb measuring and refillable reference electrode. The luminescent dissolved oxygen sensor uses lowpowered and high-speed electronics to give the sensor rapid response times and long-term stability. The HL4 turbidity sensor is International Organization for Standardization (ISO) 7027 compliant (International Organization for Standardization, 1990) and has a programmable wiper for fouling control. The sensor is corrosion resistant with a plastic sensor housing and titanium wiper shaft (OTT Hydromet, 2013b). Turbidity is the only sensor that is serviced by an active anti-fouling mechanism. Table 2 summarizes the HL4's technical specifications from the manufacturer for the sensors. 
Table 2. Technical specifications for the tested Hydrolab HL4 turbidity sensors (OTT Hydromet, 2013b).

[n/a, not applicable; ${ }^{\circ} \mathrm{C}$, degrees Celsius; $\mu \mathrm{S} / \mathrm{cm}$, microsiemens per centimeter; \%, percent; $\mathrm{mg} / \mathrm{L}$, milligram per liter; L, liter; NTU, nephelometric turbidity units]

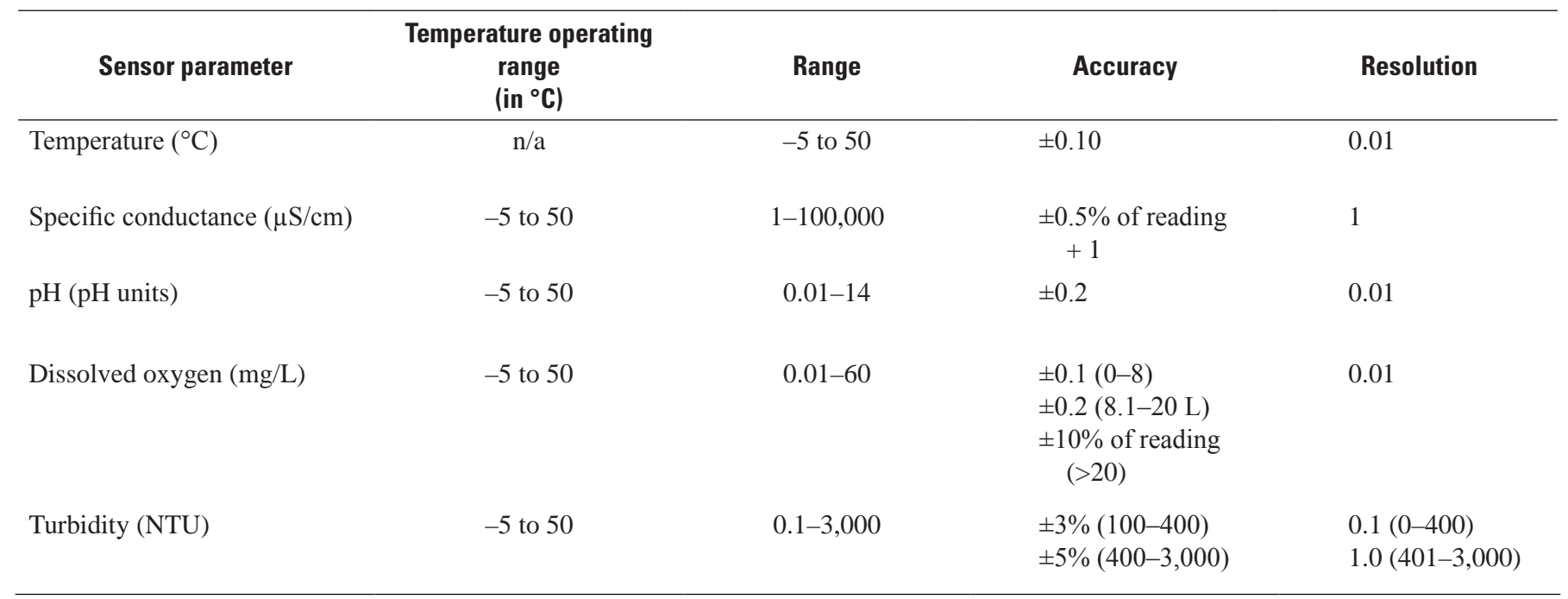

\section{Test Procedures}

\section{SDI-12 Communication}

The Hydrolab SDI-12 communications module was interfaced with an HL4 sonde and evaluated with an NR Systems SDI-12 Verifier for compliance with the SDI-12 communication standard version 1.3. The Verifier is a PC-based tool used to test the timing of SDI-12 bus transactions, which are the interactions between the sonde and data logger, and the ability of the sensors to respond correctly to SDI-12 commands. More information about the NR Systems SDI-12 Verifier can be found online at http://www.SDI-12-verifier.com. The overall ease of communication between the sondes and the computer and Surveyor HL handheld was also tested during the evaluation process.

\section{Sensor Calibrations}

Prior to testing, the HL4 water-quality sensors (sonde serial numbers 233557, 233558, and 233559) were calibrated by following the protocol stated in the Hydrolab HL4 Sensors User Manual (OTT Hydromet, 2013b), and in the calibration guidance in the Hydrolab Operating Software (OTT Hydromet, 2013c). The HL4 temperature readings were verified against a certified YSI 4600 digital thermometer calibrated to a tolerance of \pm 0.015 degree Celsius $\left({ }^{\circ} \mathrm{C}\right)$. The conductivity sensors were calibrated for SC by using a two-point calibration procedure at approximately $23{ }^{\circ} \mathrm{C}$ in air $(0 \mu \mathrm{S} / \mathrm{cm})$ and with a 1,000 -microsiemensper-centimeter $(\mu \mathrm{S} / \mathrm{cm})( \pm 0.1$ percent $)$ Ricca Chemical NIST-certified standard. DO sensors were calibrated with a single DO concentration (100 percent) in air-saturated water at $23{ }^{\circ} \mathrm{C}$. The $\mathrm{pH}$ sensors were calibrated at $23{ }^{\circ} \mathrm{C}$ by using a two-point calibration with $\mathrm{pH} 7$ and $\mathrm{pH} 4$ or $\mathrm{pH} 7$ and $\mathrm{pH} 10$ Ricca Chemical buffers. Standards used for the pH calibration were certified to be within $0.01 \mathrm{pH}$ unit of the standard value. The turbidity sensors were calibrated at room temperature with ultrapure deionized water (DI) with an 18.2-Megaohm (M $\Omega$ ) resistivity and total organic carbon concentration less than 10 parts per billion and with a 3,000-NTU standard diluted from stock formazin solution (concentration certified to be accurate within \pm 5 percent of the standard value). The Hydrolab operating software gives the user the option of a two- or four-point calibration for turbidity, and the results presented in the report are the result from a two-point calibration. When calibrated, the sensors passed the Hydrolab operating software's quality-control requirements (table 2) designed to flag errors in the calibration process.

\section{Laboratory Testing of the HL4}

Laboratory bench tests of the HL4 sensors were conducted at the HIF Water-Quality Servicing Laboratory at room temperature (approximately $25^{\circ} \mathrm{C}$ ) and at an extended temperature range of 5,15 , and $40^{\circ} \mathrm{C}$. Temperature, DO, SC, turbidity, and 
$\mathrm{pH}$ measurements were collected and compared to test controls for accuracy, which consisted of NIST-certified digital thermometers, NIST-traceable standard solutions, Winkler titrations for DO, and calculated theoretical DO values based on partial pressures of oxygen in water-saturated air. All tests of the conductivity, turbidity, and $\mathrm{pH}$ sensors were conducted using the HL4 calibration cups. Prior to testing, the HL4 calibration cups were triple-rinsed — once with the previously mentioned 18.2-M $\Omega$ DI and twice with an aliquot of the testing standard before being filled with the testing standard. The sondes were connected to a PC through a USB communication line and programmed through the Hydrolab Operating Software to log the sensor's measured values. A standard logging rate of once every 30 seconds was used for all laboratory testing. For testing conducted at 5, 15, and $40{ }^{\circ} \mathrm{C}$, the temperature of the test solution was monitored with a calibrated YSI 4600 digital thermometer. Data points that fell outside $\pm 0.4^{\circ} \mathrm{C}$ of the target temperature when the test solution temperature was stabilizing (the soak period) were disregarded. Acceptable data collected during these temperature tests for SC and pH each contained 10 to 15 valid data points per targeted temperature.

Differences between the measured and standard values were calculated and compared to the manufacturer's technical specifications and the test criteria adopted from the NFM and TD1-D3 (table 3). Sensor accuracy was determined by the percent difference between the mean of three to five replicates of the measured parameter and the standard value. Difference was calculated as measured minus standard; therefore, positive values indicated a high bias in the measured data, and negative values indicated a low bias in the measured data. The percent difference was calculated by using equation 1 .

$$
\text { Percent Difference }=100 \times \frac{\text { Mean Measured Value }- \text { Standard Value }}{\text { Standard Value }}
$$

Table 3. Test criteria derived from the NFM (Gibs and others, 2007) and TM1-D3 (Wagner and others, 2006).

[NFM, USGS National Field Manual for Collection of Water-Quality Data; TM1-D3, U.S. Geological Survey Techniques and Methods, book 1, chap. D3; $\mu \mathrm{S} / \mathrm{cm}$, microsiemens per centimeter; ${ }^{\circ} \mathrm{C}$, degrees Celsius; \%, percent; $\mathrm{mg} / \mathrm{L}$, milligram per liter; sat., saturation; FNU, formazin nephelometric units; NTU, nephelometric turbidity units; w.i.g., whichever is greater]

\begin{tabular}{ll}
\hline \multicolumn{1}{c}{ Measurement } & \multicolumn{1}{c}{ Test criteria } \\
\hline Temperature & $\pm 0.2^{\circ} \mathrm{C}$ \\
Specific conductance & \pm 5 percent $(\leq 100 \mu \mathrm{S} / \mathrm{cm})$ or \pm 3 percent $(>100 \mu \mathrm{S} / \mathrm{cm})$ \\
Dissolved oxygen & $\pm 0.3 \mathrm{mg} / \mathrm{L}$ \\
$\mathrm{pH}$ & $\pm 0.2 \mathrm{pH}$ unit \\
Turbidity & $\pm 0.5 \mathrm{FNU}^{1}$ or $\pm 5 \%$ of the measured value, w.i.g
\end{tabular}

${ }^{1}$ FNU and NTU are not directly interchangeable, but are considered equivalent for the purposes of this report. NTU was used when standards were used to judge accuracy; FNU was used when measuring environmental samples.

\section{Temperature Testing}

Temperature is an important and essential water-quality parameter because many processes and physical properties vary as a function of it. Temperature readings are collected because of its effect on chemical reactions and aquatic biota and to provide temperature compensation for water-quality parameters such as pH, SC, and DO. The HL4 measures temperature with an independent sensor supplied with the sonde. Temperature accuracy was tested on three different HL4 sondes. Measured temperatures were collected at $5{ }^{\circ} \mathrm{C}, 15^{\circ} \mathrm{C}$, room temperature (approximately $25^{\circ} \mathrm{C}$ ), and $40^{\circ} \mathrm{C}$. The accuracy of the HL4 temperature probes were compared to a certified and accuracy-verified YSI 4600 digital thermometer, and accuracy was determined by the percent difference between these values. 


\section{Specific Conductance (SC) Testing}

Three conductivity sensors were evaluated for specific conductance at room temperature in NIST-traceable SC standards: $50,100,250,500,1,000,2,500,5,000,10,000,50,000$, and 100,000 $\mu \mathrm{S} / \mathrm{cm}$. All three sensors were evaluated in the same standards, and the mean of five replicates in each standard was calculated. Following the recommendations of OTT Hydromet, the default temperature-compensation method, Hydrolab Fresh, was used by all three sondes to calculate specific conductance. To collect the data, each HL4 sonde was connected to a PC using the USB communications module and was programmed to internally log the measured values by using the Hydrolab Operating Software package.

In addition to the room-temperature testing, the sensors also were evaluated at 5, 15, and $40{ }^{\circ} \mathrm{C}$ in two SC standards: 100 and 10,000 $\mu \mathrm{S} / \mathrm{cm}$. To collect this data, the sondes were connected to three Surveyor HL handheld meters (Hydrolab). The sensors and a calibrated digital thermometer were submerged in the first SC standard $(100 \mu \mathrm{S} / \mathrm{cm})$ and were placed into the ESPECbrand environmental test chamber. The test chamber allows the user to manipulate temperature and subject the device to harsh temperatures. The chamber was programmed for the first targeted temperature. SC data from the three sensors in the SC standard at each temperature were collected, and measurements collected outside $\pm 0.4{ }^{\circ} \mathrm{C}$ of the targeted temperature were disregarded. Five to 10 measurements for each sonde were averaged at each target temperature, and the mean value was compared to the standard value listed on the certificate of analysis. The temperature-adjusted standard values were used to compare sensor measurements at 5 and $40^{\circ} \mathrm{C}$. This process was repeated with the $10,000-\mu \mathrm{S} / \mathrm{cm} \mathrm{SC}$ standard. All SC standards used in the evaluation were accurate within \pm 0.4 percent of the standard value.

\section{Dissolved Oxygen (DO) Testing}

The three DO sensors were evaluated at four concentrations with theoretical values of 0 milligrams per liter (mg/L), $2.14 \mathrm{mg} / \mathrm{L}, 8.26 \mathrm{mg} / \mathrm{L}$, and $13.11 \mathrm{mg} / \mathrm{L}$ (International Organization for Standardization, 2014). Sensor accuracy was determined by comparing the sensor's measured DO concentration to the theoretical value of oxygen in water-saturated air, and to DO concentrations measured by a Winkler titration using Standard Methods 4500-O C, Azide Modification. Standard Methods 4500-O C specifies a measurement uncertainty of $0.1 \mathrm{mg} / \mathrm{L}$, but also acknowledges the potential of greater errors in testing environmental waters (American Public Health Association, 1989). Four measured values (replicates) per sensor were collected at each concentration. The mean of each set of replicates was compared to the theoretical values and the concentrations from the Winkler titrations. Three Surveyor HL handhelds were used to communicate to the sondes and provided the measured DO values, temperature of the measured values, and the barometric pressure (BP) during testing. The BP reported by the Surveyor HL handhelds was confirmed prior to testing with a calibrated Mensor barometer. The value of the theoretical DO concentration was calculated using Henry's Law,

$$
p=k_{H} c,
$$

where
$p=\quad$ the partial pressure of a gas above the solution in atmospheres;
$c=$ the concentration of the gas in the solution in moles per liter; and
$k_{H}=\quad$ Henry's constant in moles per atmosphere.

Henry's Law states that the amount of a gas that dissolves in a solution at a constant temperature is directly proportional to the partial pressure of the gas in equilibrium with the solution (Battino and Clever, 1966).

The two lowest DO concentrations were created in a sealed bath of $18.2 \mathrm{M} \Omega$ ultrapure DI. The oxygen-depleted $(0 \mathrm{mg} / \mathrm{L})$ DO concentration was prepared by pumping 100 percent nitrogen gas into the sealed water bath at room temperature. The sparging process took approximately 60 minutes to complete, and the water temperature and the barometric pressure were carefully monitored during the process to ensure that a stable environment was maintained. BP was 760.2 millimeters of mercury (mmHg) at $23.5^{\circ} \mathrm{C}$ when the measurements for the oxygen-depleted DO test were collected. The $2.14-\mathrm{mg} / \mathrm{L}$ theoretical DO concentration was created by introducing a gas mixture of 95 percent nitrogen and 5 percent oxygen into the sealed water bath at room temperature. The water bath was sparged with the gas mixture for approximately 60 minutes until the DO concentration stabilized near 24 percent. The BP at the time of the 2.14-mg/L DO measurements was $760.1 \mathrm{mmHg}$ at $23{ }^{\circ} \mathrm{C}$.

To create the 8.26-mg/L DO concentration test conditions, a water bath at room temperature was aerated for 4 hours by using an air stone connected to a small aquarium pump until the water was fully saturated. To create the theoretical DO concentration of $13.11 \mathrm{mg} / \mathrm{L}$, this fully aerated water bath was chilled to $5{ }^{\circ} \mathrm{C}$ in an ESPEC environmental chamber. Water-bath temperature was monitored by using the NIST-certified YSI 4600 digital thermometer. The three HL4 sondes were tested simultaneously in the same water bath to ensure uniformity in the testing conditions. BP at the time of the 8.26- and 13.11-mg/L DO concentrations was $759.0 \mathrm{mmHg}$. 


\section{pH Testing}

Three $\mathrm{pH}$ sensors were evaluated at room temperature (approximately $25^{\circ} \mathrm{C}$ ) in $\mathrm{pH}$ standards $1.68,3.01,4.01,5.00,6.87$, 7.00. 9.20, 10.0, 11.00, and 12.45; these sensors were also evaluated at 5,15 , and $40{ }^{\circ} \mathrm{C}$ in pH standards 5.00 and 9.20 . To collect room temperature data, each HL4 sonde was connected to a PC using the USB communications module and was programmed to internally log the measured values by using the Hydrolab Operating Software. For each standard, the sensors were submerged and given 5 minutes for the temperature to stabilize before collecting data. All three sensors were evaluated in the same standards, and the mean of five replicates in each standard was calculated and compared to the certified value of the $\mathrm{pH}$ standards at $25{ }^{\circ} \mathrm{C}$ to determine percent difference.

In addition to room temperature testing, the sensors also were evaluated at 5,15 , and $40{ }^{\circ} \mathrm{C}$ in two $\mathrm{pH}$ standards: 5.00 and 9.20. Before testing the sensors in the $\mathrm{pH} 5.00$ buffer, the HL4 sensors were first calibrated with $\mathrm{pH} 7$ and $\mathrm{pH} 4$ standards. Before testing the sensors in the pH 9.20 standard, the sensors were calibrated with $\mathrm{pH} 7$ and pH 10 standards. Data were collected by connecting the sondes to three Surveyor HL handheld monitors. The sensors were submerged in the first $\mathrm{pH}$ buffer (5.00) with a calibrated digital thermometer, and were placed into the environmental test chamber programmed for the first targeted temperature. Data from the three sensors in the $\mathrm{pH}$ buffer at each temperature were collected, but measurements collected outside $\pm 0.4{ }^{\circ} \mathrm{C}$ of the targeted temperature were disregarded. Five to 10 measurements for each sonde were averaged at each target temperature, and the mean value was compared to the temperature-adjusted $\mathrm{pH}$ value provided on the certificate of analysis. This process was repeated for $\mathrm{pH}$ buffer 9.20 . The $\mathrm{pH}$ standards used in this evaluation were certified accurate within $\pm 0.01 \mathrm{pH}$ unit at $25^{\circ} \mathrm{C}$.

\section{Turbidity Testing}

Three HL4 turbidity sensors were evaluated for accuracy at room temperature. The sensors were tested in formazin and StablCal turbidity standards of 10, 20, 40, 100, 400, 800, 1,000, 2,000, 2,500, and 3,000 NTU. The turbidity standards were manually resuspended without aeration immediately prior to sensor measurements. Five measured replicates per standard were recorded, averaged, and compared to the standard turbidity value to determine percent difference.

\section{Field Testing of the HL4}

To evaluate the HL4 in a surface-water application, an HL4 sonde equipped with temperature, conductivity, pH, DO, and turbidity sensors was deployed at USGS water-monitoring site 02492620, Pearl River at NSTL Station, Mississippi. USGS site 02492620 is located in a tidally affected reach of the East Pearl River in Hancock County, Mississippi. The water is normally fresh (less than $100 \mu \mathrm{S} / \mathrm{cm}$ ) and clear (less than $150 \mathrm{FNU}$ ), but can become brackish from tidal intrusion during times of low precipitation.

For reference purposes, the HL4 was deployed adjacent to an EXO2 site sonde equipped with similar sensors. The EXO2 site sonde was cleaned and calibration-verified weekly during the routine site visits, while the HL4 was cleaned and verified biweekly. A site log was kept to document the date and time of each site visit, site conditions, results of calibration verification, and fouling and recalibration information. The calibration procedure described in the previous section was followed for the field deployment (Wagner and others, 2006). A laboratory-calibrated and verified YSI 6920 V2-2 (field sonde [serial number 12C101328]) was temporarily deployed during the site visits to verify the accuracy of the site sonde and serve as a secondary reference for the HL4.

The recommendations from table 6.8-5 of section 6.8 of the National Field Manual, Use of Multiparameter Instruments for Routine Field Measurements (Gibs and others, 2007), were used as the test criteria for the field test (table 4). Because each sonde accuracy is assumed to meet at least the maximum critieria listed in table 6.8-5, the acceptance criteria was established as twice the criteria listed in table 6.8-5. To meet the test criteria, the averaged differences between the HL4 sensors and the site monitor's sensors should be less than or equal to the acceptance criteria; however, measurement differences greater than the test criteria do not necessarily indicate a failure in performance due to potential variation in measurement timing, deployment depth, and potential dissimilarities in the processing of raw data between the sondes. Data from the sondes were examined for agreement in the general characteristics of the water body, and also for patterns such as highs, lows, and diurnal flows. 
Table 4. Test critieria for field deployment evaluation of the Hydrolab HL4 sensors.

$\left[{ }^{\circ} \mathrm{C}\right.$, degrees Celsius; $\mu \mathrm{S} / \mathrm{cm}$, microsiemens per centimeter; \%, percent; $\mathrm{mg} / \mathrm{L}$, milligrams per liter; $\mathrm{FNU}$, formazin nephelometric units]

\begin{tabular}{lll}
\hline \multicolumn{1}{c}{ Sensor parameter } & \multicolumn{1}{c}{ Test criteria } \\
\hline Temperature $\left({ }^{\circ} \mathrm{C}\right)$ & \pm 0.4 & \\
Specific conductance $(\mu \mathrm{S} / \mathrm{cm})$ & $\pm 10 \%$ of reading ${ }^{1}$ & \\
Dissolved oxygen $(\mathrm{mg} / \mathrm{L})$ & \pm 0.6 \\
$\mathrm{pH}(\mathrm{pH}$ units) & $\pm 0.6^{2}$ \\
Turbidity (FNU) & $\pm 10 \%$ of reading \\
\hline
\end{tabular}

${ }^{1}$ Criterion based upon an average specific conductance of less than $100 \mu \mathrm{S} / \mathrm{cm}$ (Gibs and others, 2007).

${ }^{2}$ Criterion based upon the measurement of pH in low ionic-strength water (Gibs and others, 2007).

\section{Test Results}

\section{SDI-12 Communication}

The Hydrolab SDI-12 communications module passed the NR Systems SDI-12 verification test for SDI-12 communication protocol, version 1.3. The SDI-12 test verifies adherence to SDI-12 communication requirements including proper response to SDI-12 commands and break signals, proper data retrieval and holds, and acceptable timing for bus transactions. The fitting on the HL4 calibration cable has a recessed five-pin connection that interfaces the HL4 to the Surveyor HL handheld or to the USB communications module for use with a PC. The pins in this connection fitting were found to bend easily; therefore, the end user should exercise care when connecting or disconnecting the cable.

\section{Laboratory Testing of the HL4}

Results for laboratory bench testing are described in the following sections. Vertical error bars in the result figures represent an estimate of the overall uncertainty of the standard value and were calculated from a simple addition of the contributing error. The standard uncertainties include error in the accuracy of the digital thermometer used to measure temperature, error contributed by uncertainty of the purchased standards, and error contributed by the preparation of standard dilutions if applicable. In addition to these standard uncertainties, the error bars for DO include the standard uncertainty of the Mensor barometer used to measure atmospheric pressure and the error associated with the Standard Methods 4500-O C Winkler titrations.

\section{Temperature Results}

The temperature sensors on three HL4 sondes were tested in varying temperatures ranging from approximately 5 to $40{ }^{\circ} \mathrm{C}$. Datasets for the three sensors contained approximately 25 to 50 data points each. Statistics from the datasets varied (table 5). All three sensors met the $\pm 0.2-{ }^{\circ} \mathrm{C}$ USGS criterion and the manufacturing technical specifications of $\pm 0.1{ }^{\circ} \mathrm{C}$ at room temperature based upon the median difference between the measured and standard temperatures. Accuracy of the sensors varied when subjected to temperatures other than approximately $25^{\circ} \mathrm{C}$, with the largest differences occurring between the measured temperatures and the calibrated digital thermometer at the temperature extremes $\left(5\right.$ and $40^{\circ} \mathrm{C}$ ) of the test.

The sonde guards did not fare well during the tests and warped substantially during the temperature ramp (fig. 2). When notified about the warping, OTT Hydromet tested some additional guards at their facility at the low and high ranges of the temperature operating range, and was unable to repeat the results. It was theorized that the warping was caused not from the temperature extremes themselves, but as a result of the temperature cycling from low temperature to high. 
Table 5. Temperature statistical data from testing of three Hydrolab HL4 sondes.

$\left[{ }^{\circ} \mathrm{C}\right.$, degrees Celsius $]$

\begin{tabular}{|c|c|c|c|c|c|}
\hline Sonde ID & Statistic & $5^{\circ} \mathrm{C}$ & $15^{\circ} \mathrm{C}$ & $25^{\circ} \mathrm{C}$ & $40^{\circ} \mathrm{C}$ \\
\hline \multirow[t]{3}{*}{233557} & Median difference & -0.09 & 0.02 & 0.09 & -0.05 \\
\hline & Minimum difference & -0.44 & -0.48 & -0.42 & -1.09 \\
\hline & Maximum difference & 0.60 & 0.40 & 0.38 & 0.01 \\
\hline Sonde ID & Statistic & $5^{\circ} \mathrm{C}$ & $15^{\circ} \mathrm{C}$ & $25^{\circ} \mathrm{C}$ & $40^{\circ} \mathrm{C}$ \\
\hline \multirow[t]{3}{*}{233558} & Median difference & -0.03 & -0.08 & -0.08 & 0.40 \\
\hline & Minimum difference & -0.40 & -0.40 & -0.43 & 0.02 \\
\hline & Maximum difference & 0.22 & 0.14 & 0.47 & 0.84 \\
\hline Sonde ID & Statistic & $5^{\circ} \mathrm{C}$ & $15^{\circ} \mathrm{C}$ & $25^{\circ} \mathrm{C}$ & $40^{\circ} \mathrm{C}$ \\
\hline \multirow[t]{3}{*}{233559} & Median difference & -0.21 & 0.07 & -0.09 & 0.04 \\
\hline & Minimum difference & -0.22 & -0.42 & -0.42 & -1.09 \\
\hline & Maximum difference & 0.10 & 0.39 & 0.14 & 0.92 \\
\hline
\end{tabular}
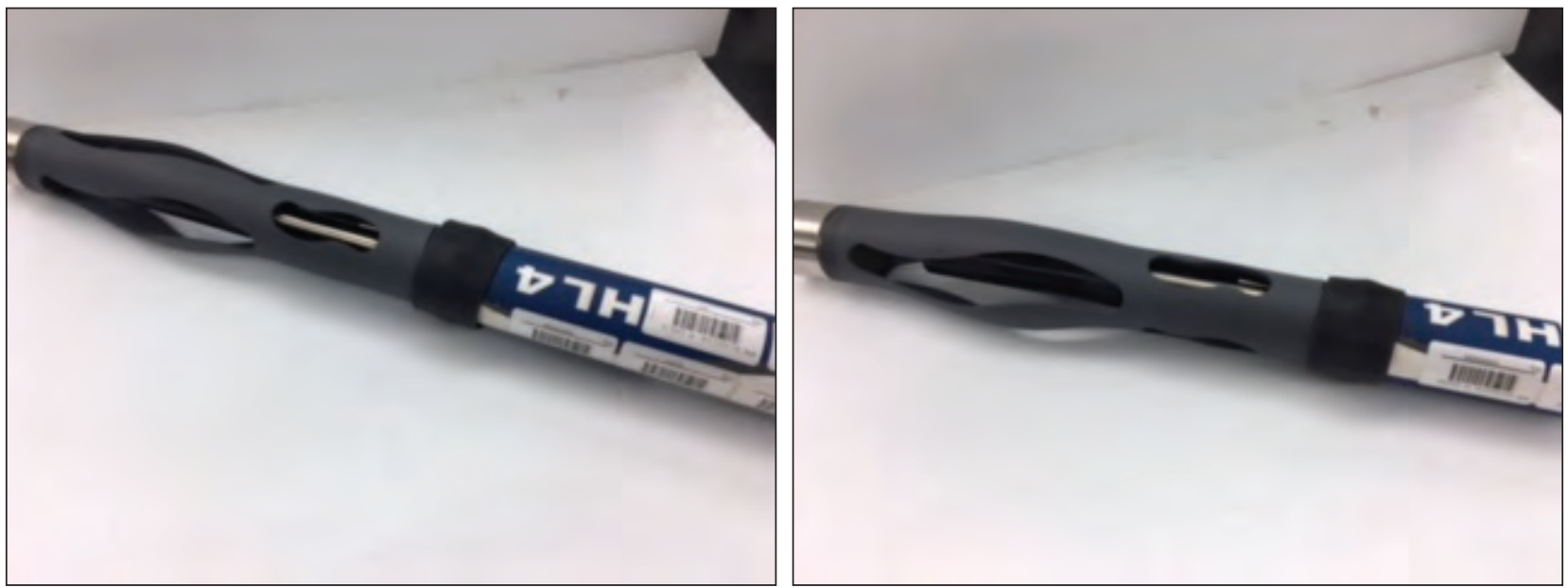

Figure 2. HL4 sonde with warped sensor guard after the initial ramped temperature test. 


\section{Specific Conductance Results}

The results from the room temperature accuracy tests showed that two out of three conductivity sensors met the test criteria of \pm 5 percent $(\leq 100 \mu \mathrm{S} / \mathrm{cm})$ and \pm 3 percent $(>100 \mu \mathrm{S} / \mathrm{cm})$ (Wagner and others, 2006; Gibs and others, 2007) for SC. Sonde 233558 exceeded the test criteria in the $100,000-\mu \mathrm{S} / \mathrm{cm}$ standard with a -3.69 -percent difference from the standard value. The more stringent manufacturer's technical specification of \pm 0.5 percent plus $1 \mu \mathrm{S} / \mathrm{cm}$ was exceeded by sonde 233557 in the 1,000 - and $2,500-\mu \mathrm{S} / \mathrm{cm}$ standards. In addition to exceeding the test criteria, sonde 233558 also failed to meet the manufacturer's technical specifications in the 100-, 500-, 1,000-, 2,500-, and 50,000- $\mu \mathrm{S} / \mathrm{cm}$ standards. Sonde 233559 failed to meet the manufacturer's technical specifications only in the $1,000-$ and $2,500-\mu \mathrm{S} / \mathrm{cm}$ standards (fig. 3 ).

The sensors were not recalibrated prior to the extended temperature-range testing. Sonde 233557 met the testing criteria in the $100-\mu \mathrm{S} / \mathrm{cm}$ and the $10,000-\mu \mathrm{S} / \mathrm{cm}$ standards, at all four temperatures $\left(5,15,25\right.$, and $\left.40^{\circ} \mathrm{C}\right)$ when test uncertainty of \pm 1.4 percent was included (fig. 4). Sonde 233557 met the technical specifications in the $100-\mu \mathrm{S} / \mathrm{cm}$ standard at 5 and $25^{\circ} \mathrm{C}$, and also met the technical specifications in the $10,000-\mu \mathrm{S} / \mathrm{cm}$ standard at 25 and $40{ }^{\circ} \mathrm{C}$. Sonde 233558 met the test criteria in the $100-\mu \mathrm{S} / \mathrm{cm}$ standard at 5,25 , and $40{ }^{\circ} \mathrm{C}$, but failed to meet the manufacturer's technical specifications except in the $10,000-\mu \mathrm{S} / \mathrm{cm}$ at $25^{\circ} \mathrm{C}$. Sonde 233558 met the test criteria in the $10,000-\mu \mathrm{S} / \mathrm{cm}$ standard at all four temperatures. Sonde 233559 met the test criteria in the $100-\mu \mathrm{S} / \mathrm{cm}$ standard at 5,25 , and $40{ }^{\circ} \mathrm{C}$, and in the $10,000-\mu \mathrm{S} / \mathrm{cm}$ standard only at $25^{\circ} \mathrm{C}$. Sonde 233559 failed to meet the technical specifications in the $100-\mu \mathrm{S} / \mathrm{cm}$ standard at all temperatures, but met the technical specifications in the $10,000 \mu \mathrm{S} / \mathrm{cm}$ standard at $25^{\circ} \mathrm{C}$.

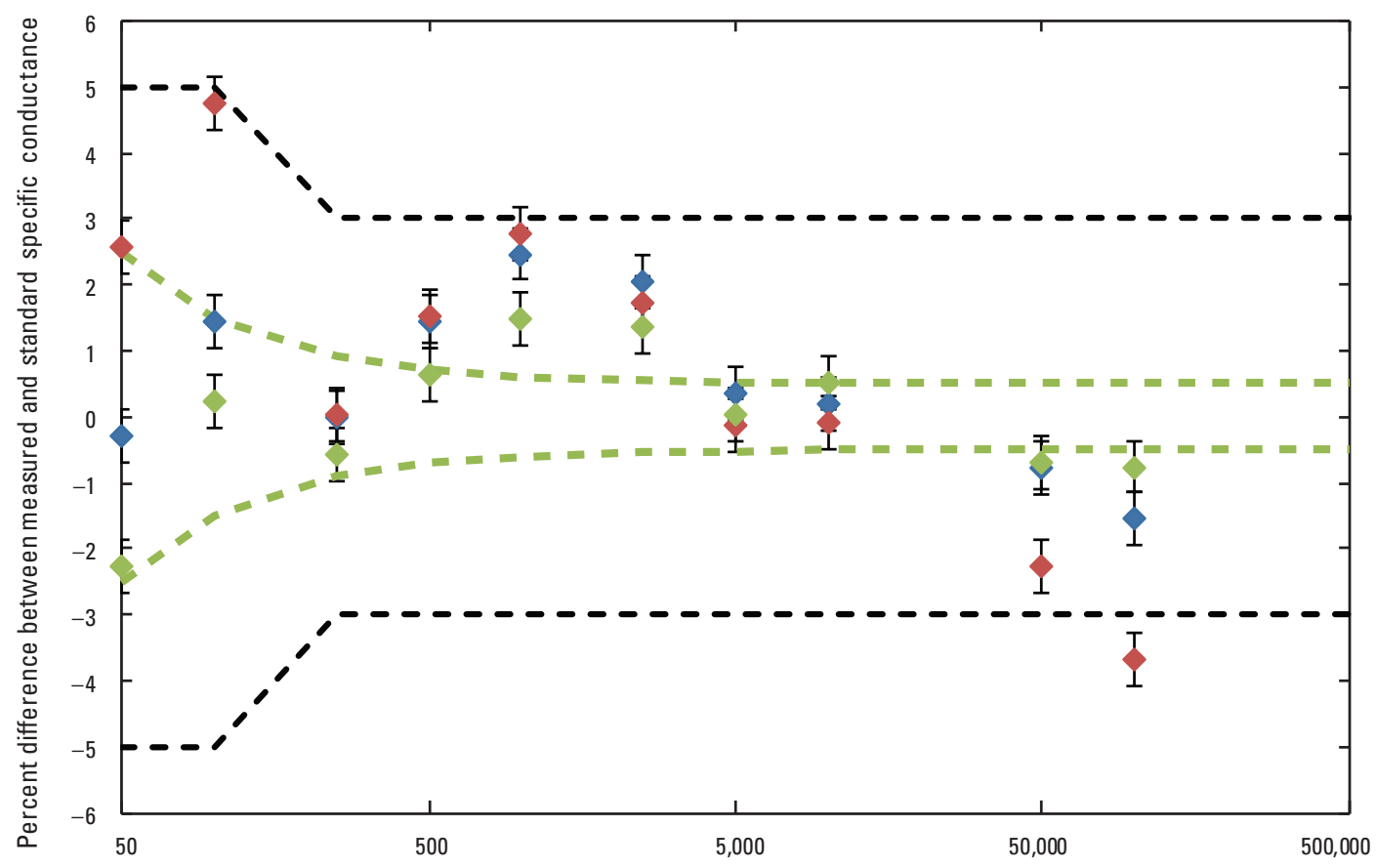

Logarithmic scale showing specific conductance standard values, in microsiemens per centimeter

EXPLANATION

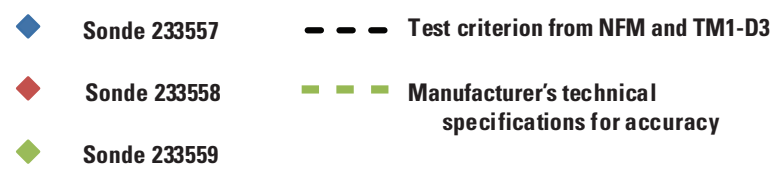

Figure 3. The percent difference for three HL4 sensors between the measured specific conductance (SC) and the standard values at room temperature. Error bars represent the \pm 0.4 -percent uncertainty from the NIST-traceable SC standards at 95 percent confidence. 

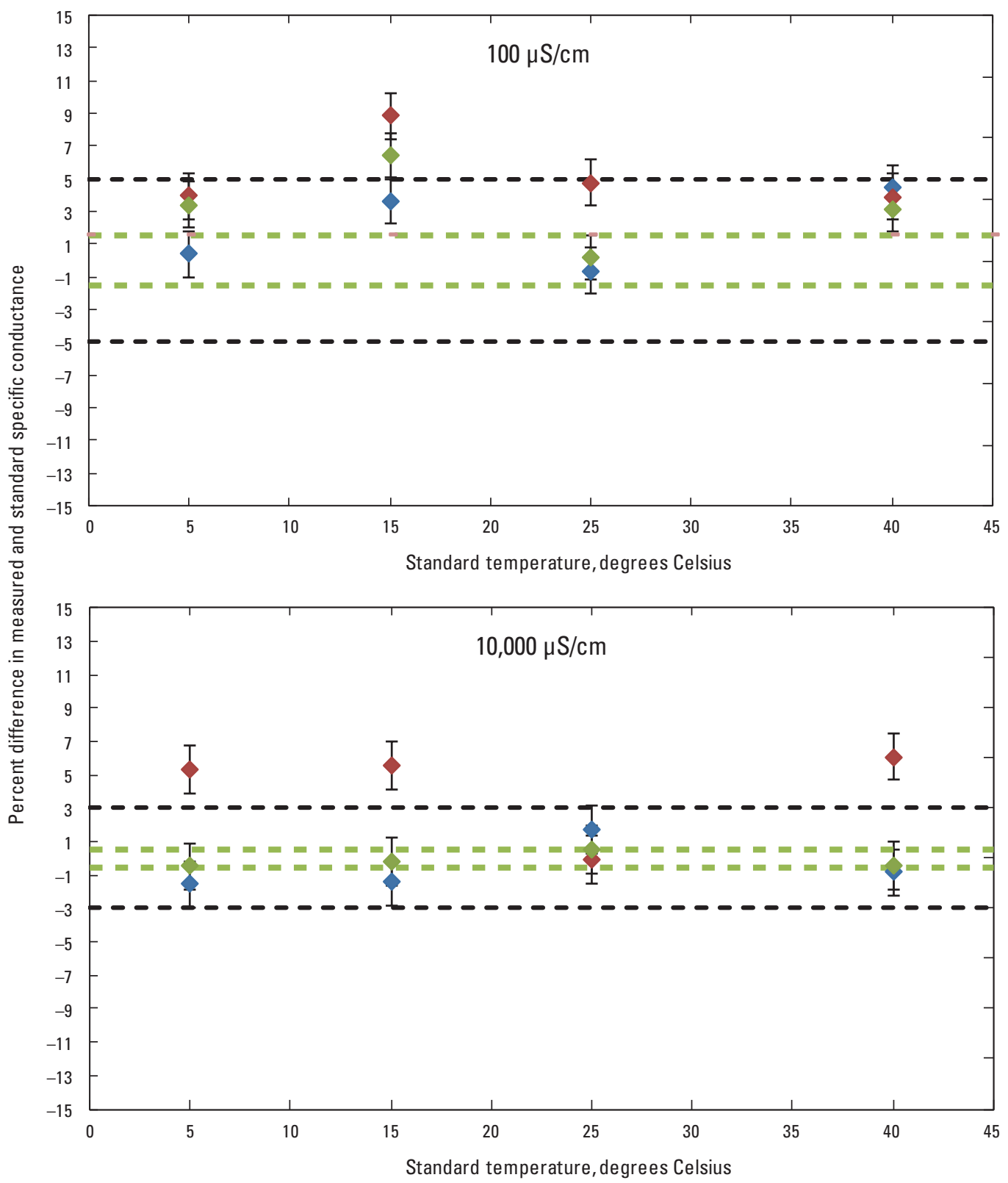

\section{EXPLANATION}

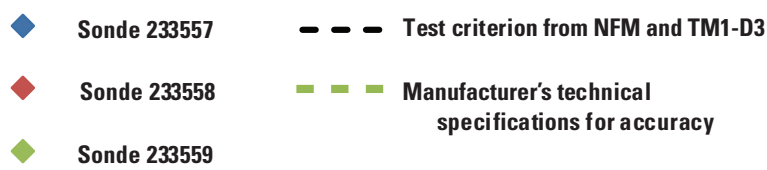

Figure 4. The percent difference for three HL4 sensors between the measured specific conductance (SC) values and standard values in 100- and 10,000-microsiemens-per-centimeter standards at 5, 15, 25, and $40^{\circ} \mathrm{C}$. Error bars represent the \pm 1 .4-percent uncertainty of the test that included standard uncertainty at temperatures other than $25^{\circ} \mathrm{C}$, and error contributed by the digital thermometer, at 95 percent confidence. 


\section{pH Results}

The $\mathrm{pH}$ sensors on three HL4 sondes were subjected to nine standards at room temperature: $1.60,3.01,4.00,5.00,6.87$, 7.0, 9.18, 10.03, and 12.45 The sensors also were subjected to two standards at 5,15 , and $40{ }^{\circ} \mathrm{C}: 5.00$ and 9.18 . For $\mathrm{pH}$, the manufacturing technical specification matched the NFM test criteria at $\pm 0.2 \mathrm{pH}$ unit. All three sensors met the test criteria and the technical specifications at room temperature (fig. 5), and sondes 233558 and 233559 met the requirements in pH 5.00 and pH 9.18 at the extended temperatures (fig. 6). Sensor 233557 exceeded the $\pm 0.2 \mathrm{pH}$ unit with a $0.23 \mathrm{pH}$ unit difference between the measured and standard value in the $\mathrm{pH} 5.00$ standard.

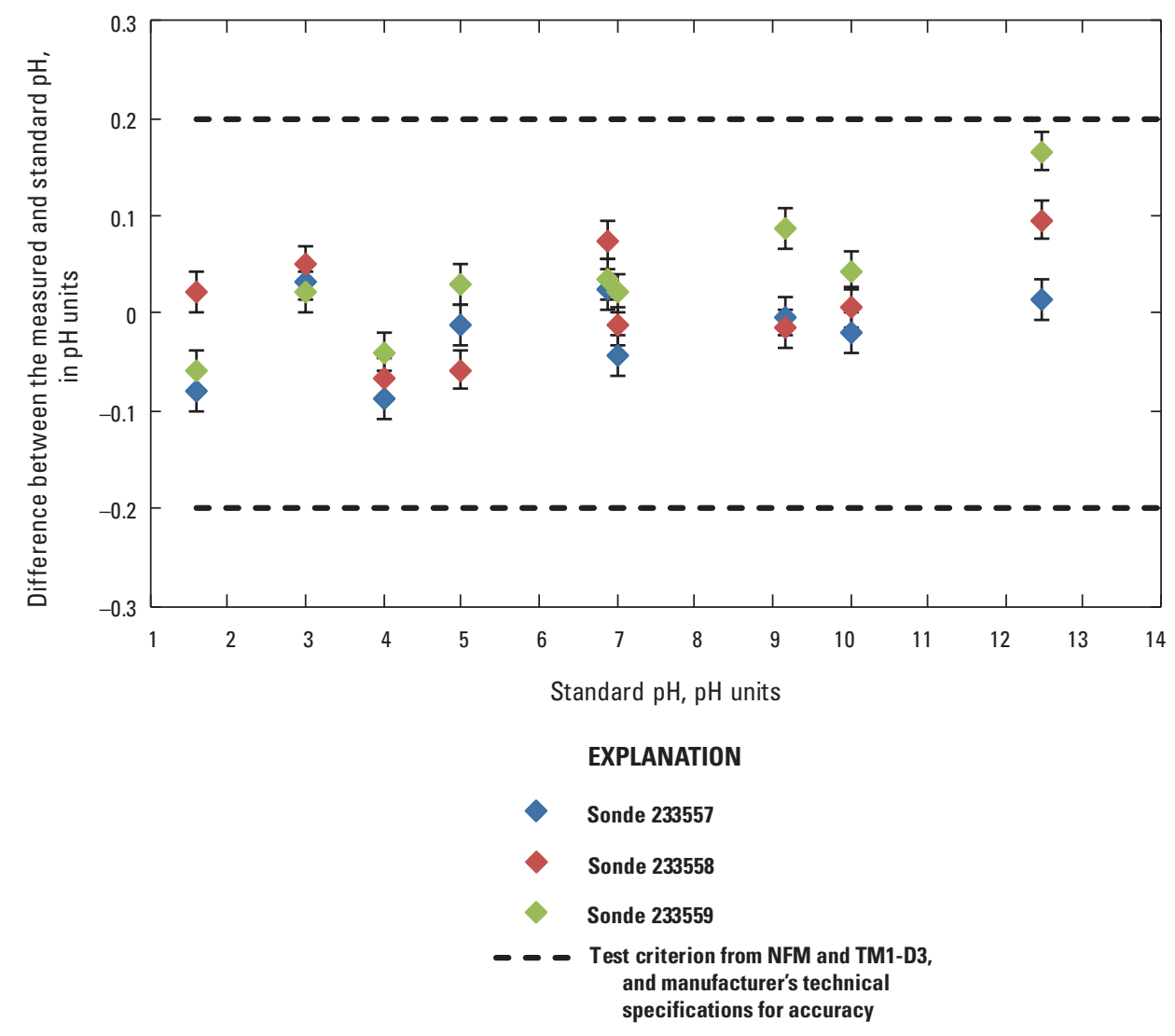

Figure 5. The difference in measured and standard pH from three Hydrolab HL4 sondes in $1.68,3.01,4.00,5.00,6.86,7.00,9.18,10.03$, and $12.45 \mathrm{pH}$ standards at room temperature. Error bars represent the $0.02 \mathrm{pH}$ unit uncertainty from the NIST-traceable $\mathrm{pH}$ standards at 95 percent confidence. 

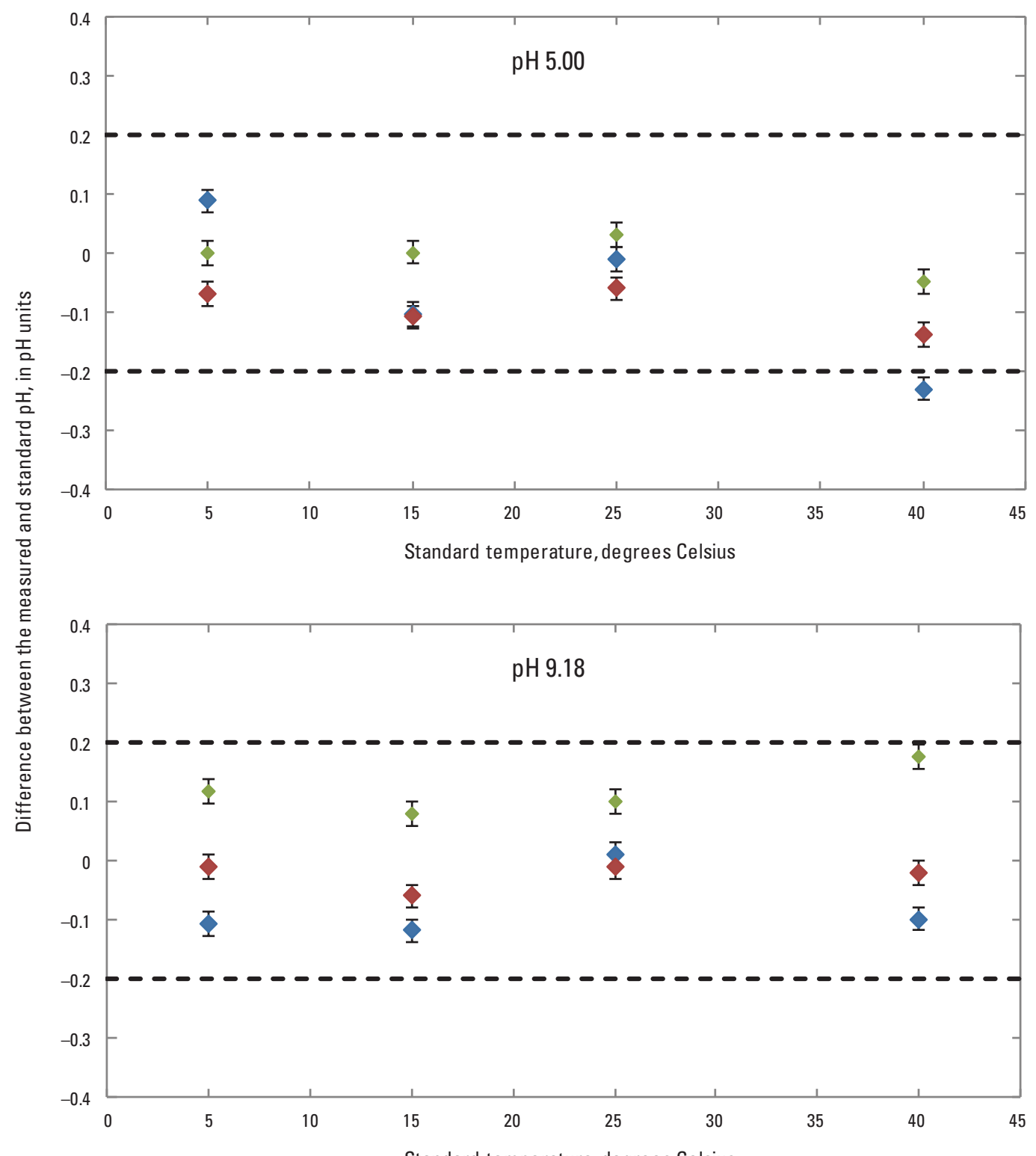

Standard temperature, degrees Celsius

\section{EXPLANATION}

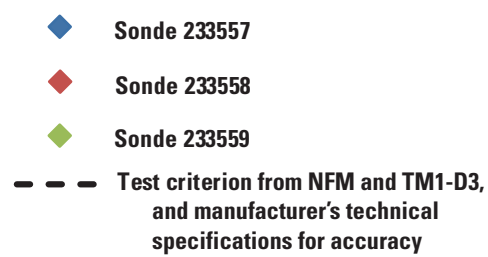

Figure 6. Results from the testing of $\mathrm{pH}$ in 5.00 and $9.18 \mathrm{pH}$ standards at 5, 15, 25, and 40 degrees Celsius. Error bars represent the $0.02 \mathrm{pH}$ unit uncertainty from the NIST-traceable $\mathrm{pH}$ standards at 95 percent confidence. 


\section{Dissolved Oxygen (DO) Results}

DO sensors on three HL4 sondes were tested for accuracy in four theoretical DO concentrations of 0, 2.14, 8.26, and $13.11 \mathrm{mg} / \mathrm{L}$. Duplicate Winkler titrations were performed at each concentration and served as the reference check. The differences between the measured DO and the Winkler titration DO are shown in figure 7, and the differences between the measured and theoretical DO are shown in figure 8. Vertical error bars shown in figure 7 represent the estimated 0.3 -mg/L uncertainty from the preparation of the Winkler titration reagents. Error bars in figure 8 represent a $0.10-\mathrm{mg} / \mathrm{L}$ uncertainty based on the manufacturers' accuracy of the Mensor barometer and the digital thermometer. Sensor measurements were precise with variations between replicates less than $\pm 0.05 \mathrm{mg} / \mathrm{L}$. All three sensors met the USGS $\pm 0.3-\mathrm{mg} / \mathrm{L}$ test criterion and mostly met the more stringent manufacturer's technical specifications when compared to the DO from the theoretical calculations and from the Winkler titrations with the estimated uncertainty included in the calculations. Sensor 233558 exceeded the $\pm 0.2 \mathrm{mg} / \mathrm{L}$ technical specifications with a $0.34 \mathrm{mg} / \mathrm{L}$ difference from the theoretical value of $2.14 \mathrm{mg} / \mathrm{L}$. The maximum difference between the measured values and those from the Winkler titrations was $0.40 \mathrm{mg} / \mathrm{L}$ from sonde 233559, which occurred at the 12.80-mg/L Winkler DO concentration (13.11 mg/L theoretical value) (fig. 7).

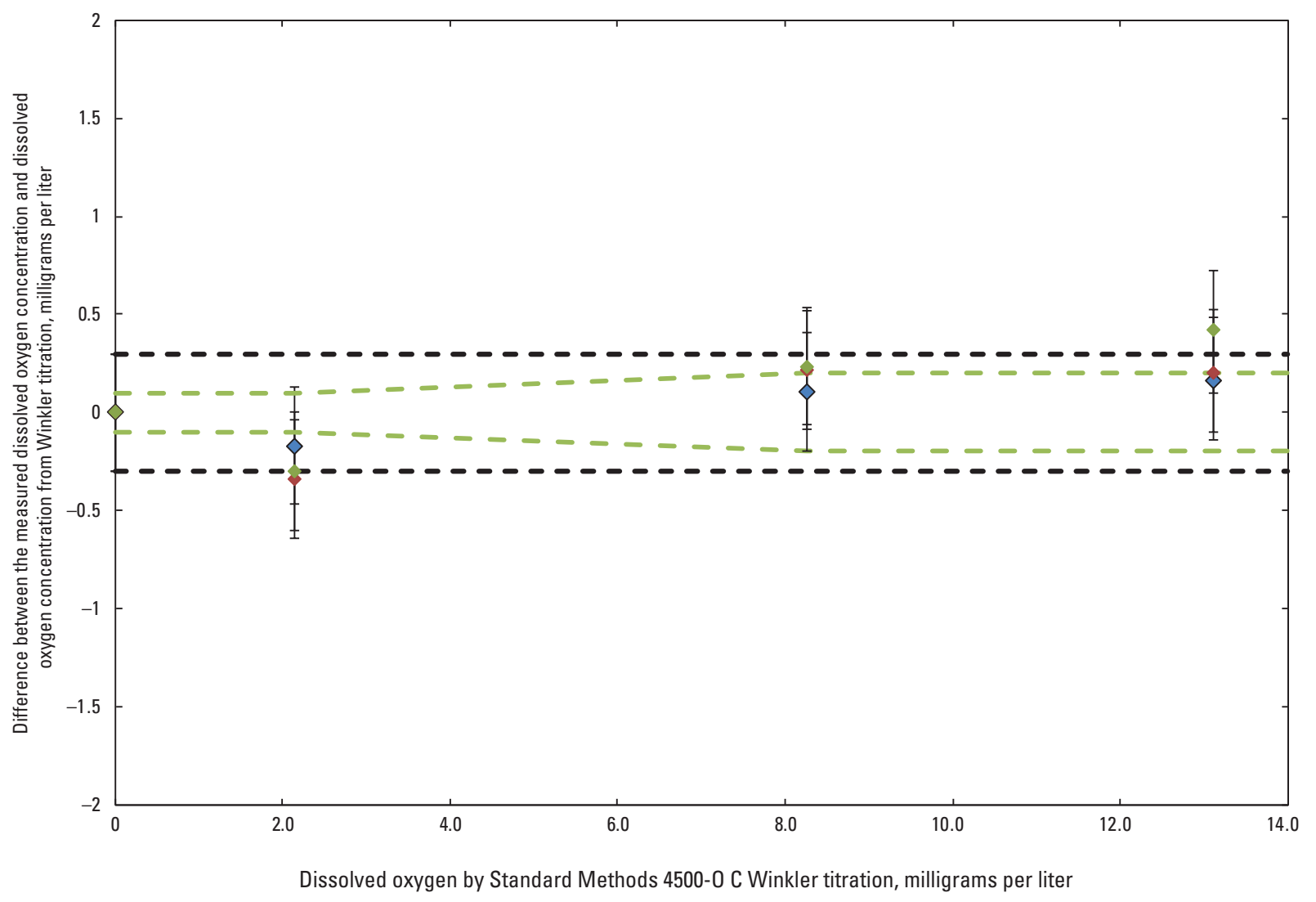

EXPLANATION

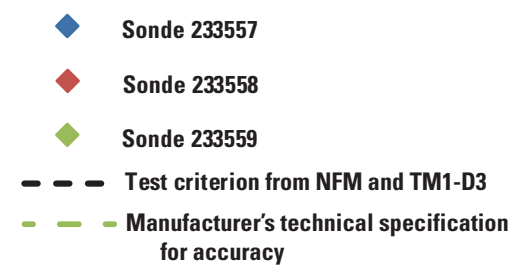

Figure 7. The differences between the measured dissolved oxygen concentrations from three Hydrolab HL4 sondes and the dissolved oxygen concentrations from Standard Methods 4500-0 C Winkler titrations at 0, 2.10, 8.20, and $12.80 \mathrm{mg} / \mathrm{L}$. Error bars represent the $0.3-\mathrm{mg} / \mathrm{L}$ uncertainty of Standard Methods 4500-0 C Winkler titrations procedure. 

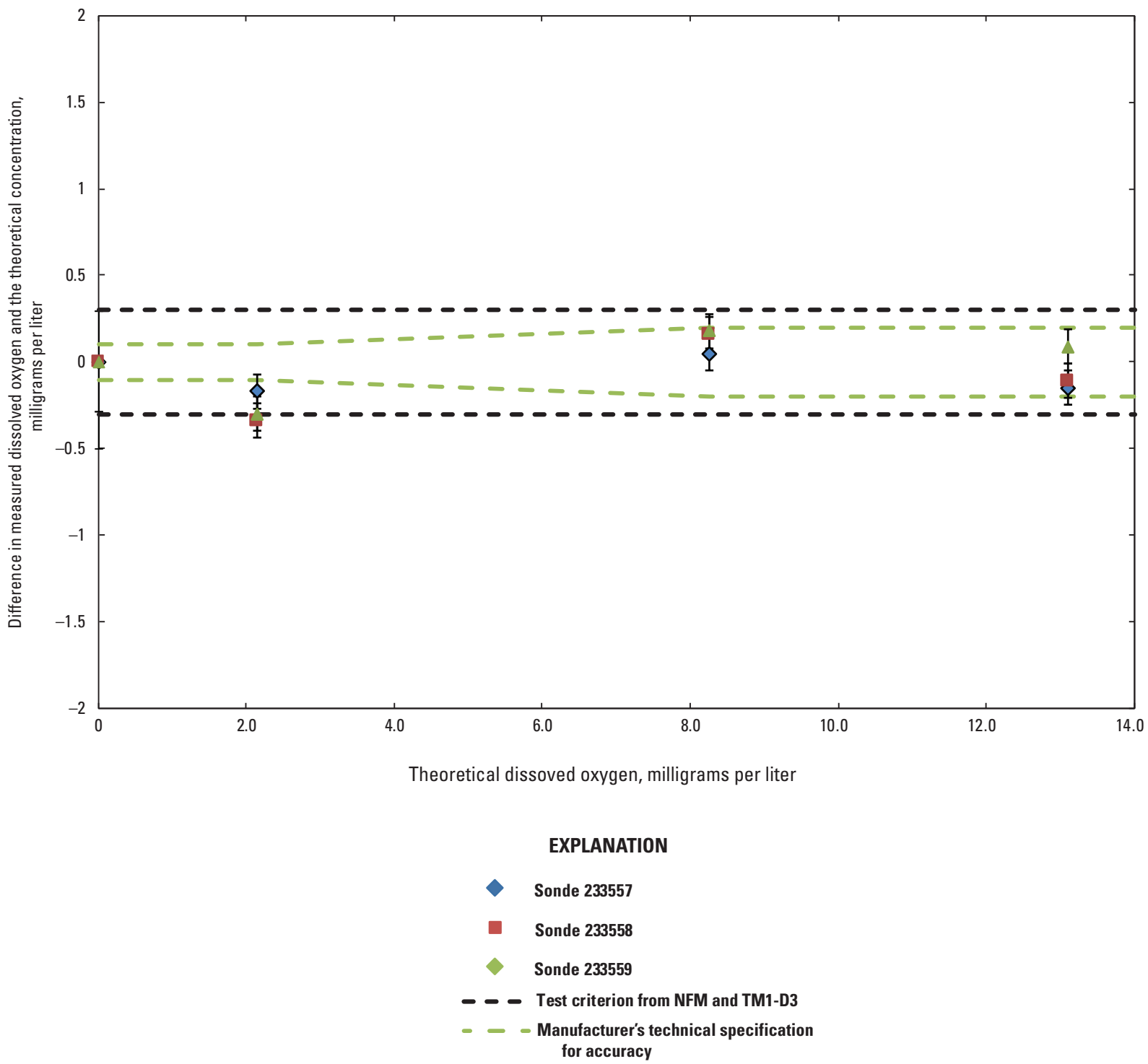

Figure 8. The differences between the measured dissolved oxygen concentrations from three Hydrolab HL4 sondes and the calculated theoretical dissolved oxygen at $0,2.14,8.26$, and $13.11 \mathrm{mg} / \mathrm{L}$. Error bars represent the $0.1-\mathrm{mg} / \mathrm{L}$ uncertainty of the theoretical dissolved oxygen values derived from uncertainty of the Mensor barometer and digital thermometer.

\section{Turbidity Results}

The results from turbidity testing of the HL4 sensors with a two-point calibration are shown in figure 9. Vertical error bars in figure 9 represent the standard uncertainty, which was estimated at 5 percent. Sonde 233557 met the \pm 5 -percent USGS calibration criterion and the technical specifications in standards ranging from 10 to 3,000 NTU. Sonde 233558 also met the USGS criteria in every standard except in the 3,000-NTU standard, where the percent difference from the standard value was -13.23 percent. The technical specifications were also met by sonde 233558 except in the 3,000-NTU standard. Sonde 233559 exceeded the USGS calibration criteria in the 10- and 20-NTU standards, but met the criteria in the rest of the standards. The technical specifications were not met in the 20-NTU standard by sonde 233559 , but were met in the 10-NTU standard due to the \pm 1 -NTU technical specification for turbidity less than 1,000 NTU. All three HL4 sensors met the test criteria in a turbidity range of 50 to 1,000 NTU, but only one of the three sensors (233557) met the criteria when evaluated at the extreme ranges of the test. 


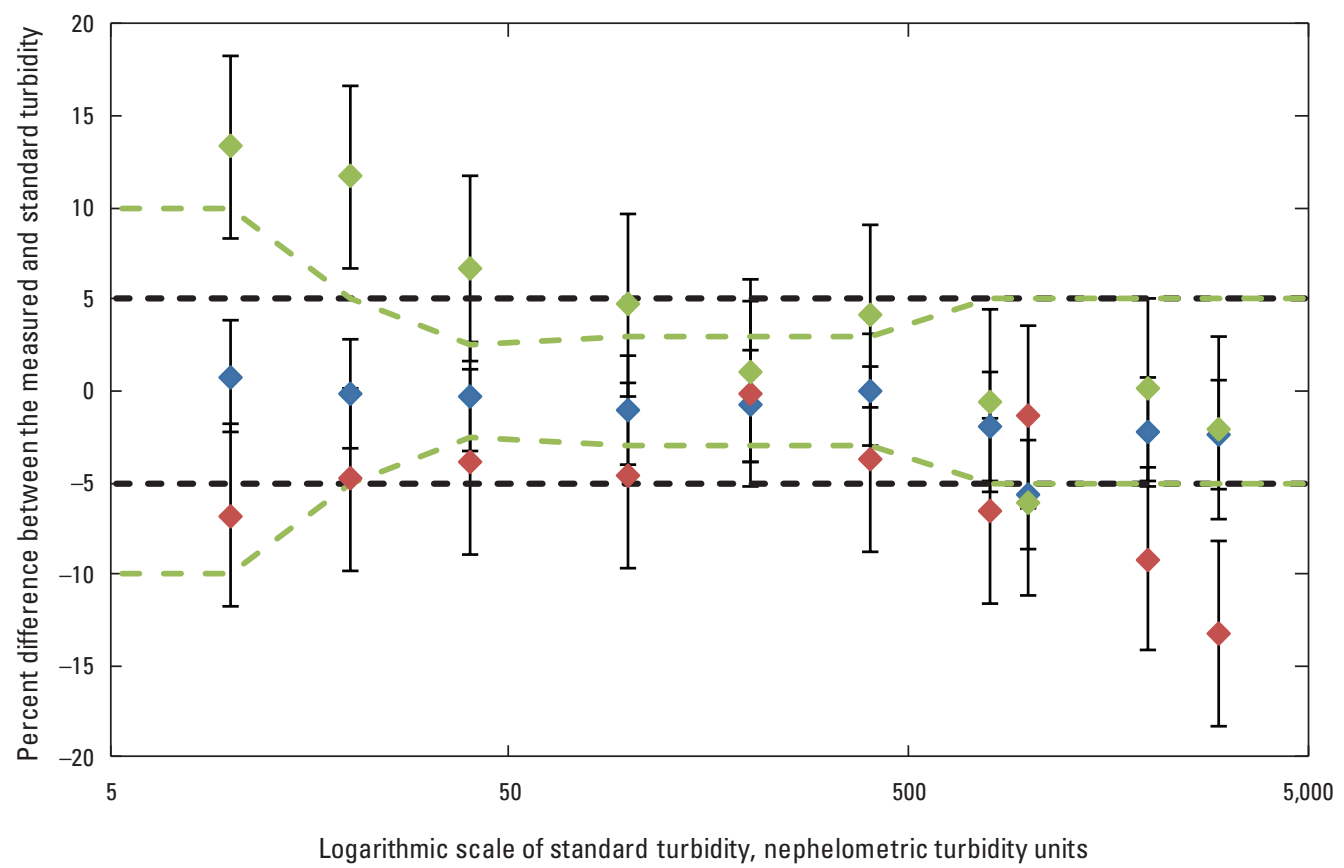

\section{EXPLANATION}

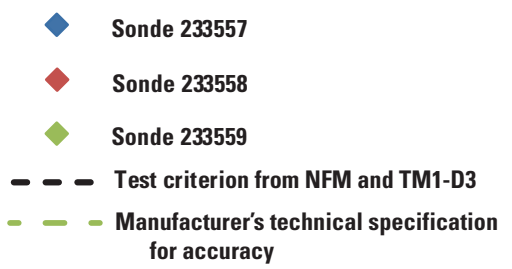

Figure 9. The percent difference between the measured turbidity from three Hydrolab HL4 sondes and the StablCal standard turbidity values, in nephelometric turbidity units (NTU). Error bars represent the 5-percent uncertainty of the formazin and StablCal turbidity standards. 


\section{Field Testing of the HL4}

A statistical summary from field comparisons between an HL4 sonde and an EXO2 site sonde is shown in table 6. The test criteria, which were $\pm 0.4{ }^{\circ} \mathrm{C}$ for temperature, \pm 10 percent for $\mathrm{SC}, \pm 0.6 \mathrm{pH}$ unit for $\mathrm{pH}$, and \pm 10 percent for turbidity, were met during the field deployment. The median difference between the HL4 sonde and the EXO2 site sonde exceeded the test criterion for DO slightly $(-0.62 \mathrm{mg} / \mathrm{L})$. The data in the hydrographs from the two sondes are similar with good agreement in diurnal and diel cycles (fig. 10). A low bias in the HL4 DO data was possibly caused by the lack of an active anti-fouling device such as a wiper.

In addition, differences in the way raw signals are processed by the two sondes could have contributed to variances in the data. Signal processing by the sonde is usually a proprietary process and the degree of processing is up to the sonde supplier. For example, some sonde suppliers filter or "smooth" the data that are reported by the sonde, while some sonde suppliers choose to allow the sonde to report all of the data unmodified in a continuous stream. Data smoothing and signal processing may produce data that have fewer "extremes" at highs and lows and can eliminate data considered to be "outliers." XYLEM and OTT Hydromet, among other vendors, use a signal processing technique known as "signal averaging," which can create smoother data with few outliers or data spikes. Differences between vendor-specific data can result from the different signal processing methods used to determine which data are considered outliers, or in specifics such as the number of signals averaged. If the monitored site is well mixed and conditions remain relatively unchanged with time, differences between vendor-specific data will be negligible regardless of differences in the signal processing method used. Users should be aware that differences in sensor data processing can change the sensor data stream and could result in data shifts.

Table 6. Summary of the field testing measurements by the EXO2 site sonde and the Hydrolab HL4 sonde at USGS site 02492620, Pearl River at NSTL Station, Mississippi, June 21-July 21, 2016.

[USGS, U.S. Geological Survey; ${ }^{\circ} \mathrm{C}$, degrees Celsius; $\mu \mathrm{S} / \mathrm{cm}$, microsiemens per centimeter; $\%$, percent; mg/L, milligrams per liter; FNU, formazin nephelometric units. Median difference is from the pairs of simultaneous measurements made by both sondes]

\begin{tabular}{lccccccc}
\hline & $\begin{array}{c}\text { HL4 } \\
\text { median }\end{array}$ & $\begin{array}{c}\text { HL4 } \\
\text { minimum }\end{array}$ & $\begin{array}{c}\text { HL4 } \\
\text { maximum }\end{array}$ & $\begin{array}{c}\text { EX02 } \\
\text { median }\end{array}$ & $\begin{array}{c}\text { EX02 } \\
\text { minimum }\end{array}$ & $\begin{array}{c}\text { EX02 } \\
\text { maximum }\end{array}$ & $\begin{array}{c}\text { Median } \\
\text { difference }\end{array}$ \\
\hline $\begin{array}{l}\text { Temperature }\left({ }^{\circ} \mathrm{C}\right) \\
29.06\end{array}$ & 28.17 & 31.49 & 29.20 & 28.41 & 31.70 & -0.14 \\
$\begin{array}{l}\text { Specific conductance } \\
(\mu \mathrm{S} / \mathrm{cm})\end{array}$ & 68.40 & 64.21 & 75.40 & 73.0 & 69.03 & 80.00 & $-6.30 \%$ \\
$\mathrm{pH}(\mathrm{pH}$ units) & 6.49 & 6.31 & 6.84 & 6.40 & 6.10 & 6.92 & 0.09 \\
$\begin{array}{l}\text { Dissolved oxygen } \\
(\mathrm{mg} / \mathrm{L})\end{array}$ & 6.38 & 4.07 & 9.68 & 7.0 & 3.81 & 10.30 & -0.62 \\
$\begin{array}{l}\text { Turbidity } \\
(\mathrm{FNU})\end{array}$ & 14.60 & 6.90 & 27.22 & 14.00 & 8.01 & 20.04 & $4.28 \%$ \\
\hline
\end{tabular}




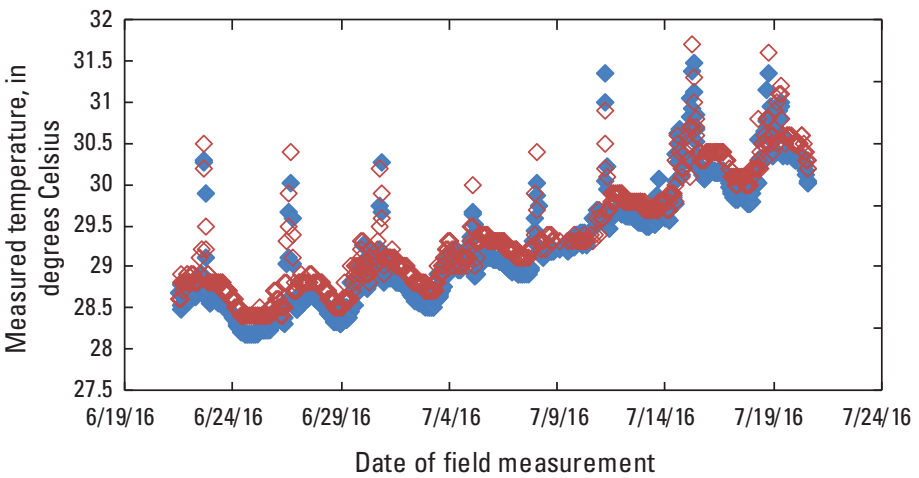

EXPLANATION

- Measured temperature by HL4

$\diamond$ Measured temperature by site sonde

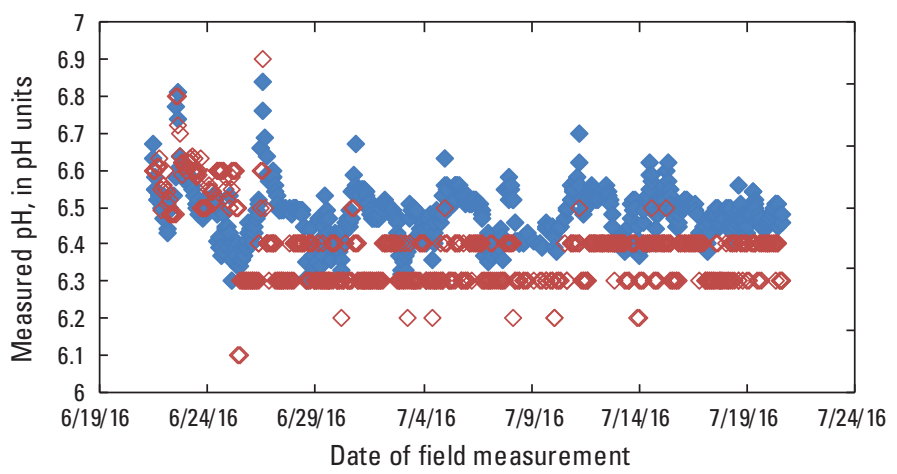

EXPLANATION

Measured pH by HL4

$\diamond$ Measured pH by site sonde

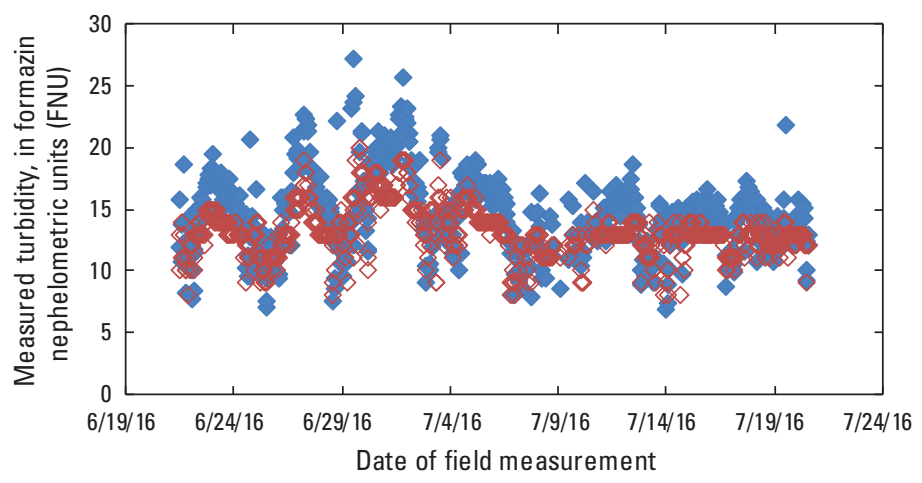

EXPLANATION

- Measured turbidity by HL4

$\diamond$ Measured turbidity by site sonde

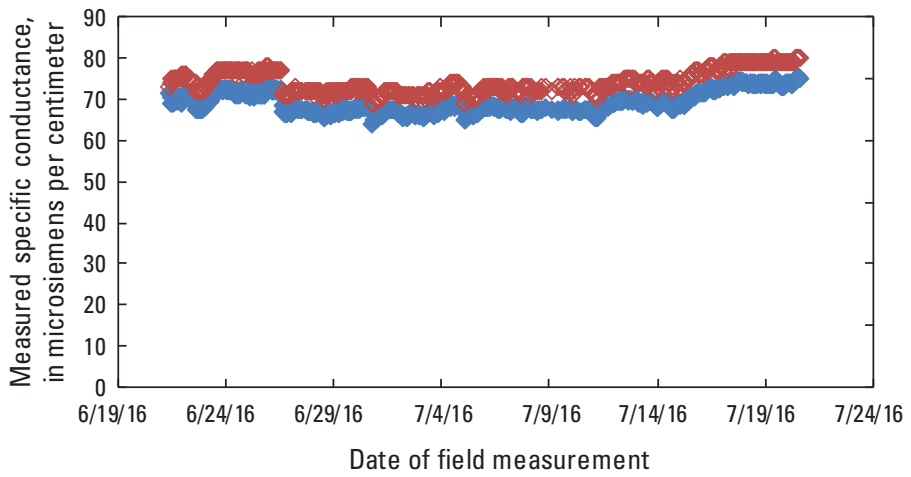

EXPLANATION

Measured specific conductance by HL4

$\diamond$ Measured specific conductance by site sonde

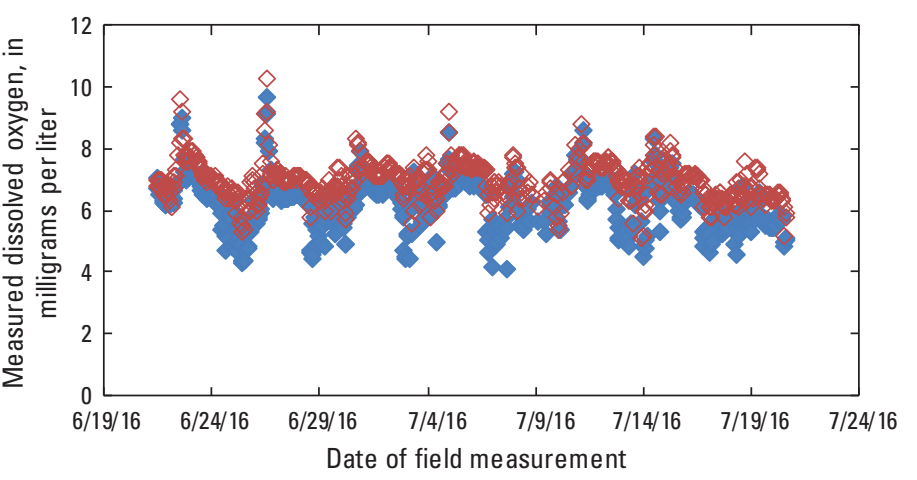

EXPLANATION

- Measured dissolved oxygen by HL4

$\diamond$ Measured dissolved oxygen by site sonde

Figure 10. Temperature, specific conductance, $\mathrm{pH}$, dissolved oxygen, and turbidity field data from the Hydrolab HL4 and EXO2 sondes. 


\section{Summary}

Three Hydrolab HL4 multiparameter water-quality sondes by OTT Hydromet were evaluated by the USGS HIF. The sondes were equipped with temperature, conductivity, pH, DO, and turbidity sensors. Sensor accuracy was tested for compliance with the USGS criteria for continuous water-quality monitors and to verify the validity of the manufacturer's technical specifications. The HL4's communication protocols and operating temperature range also were tested. To evaluate the sondes' performance in a surface-water field application, an HL4 was deployed at USGS site 02492620, Pearl River at NSTL Station, Mississippi, and compared to the permanently deployed EXO2 site sonde at that location.

Room temperature performance for SC, pH, DO, and turbidity varied among the sondes, but was mostly acceptable. Some instances of criteria exceedance occurred, mostly at the temperature extremes $\left(5\right.$ and $\left.40{ }^{\circ} \mathrm{C}\right)$ and at the lowest and highest ends of the operating range. The HL4 sondes met the USGS criterion $\left( \pm 0.2^{\circ} \mathrm{C}\right)$ and the manufacturer's technical specifications of $\pm 0.1{ }^{\circ} \mathrm{C}$ at room temperature based upon the median difference between the measured and standard temperatures, but two of the three sondes (233558 and 233559) failed to meet the criterion at the temperature extremes of approximately 5 and $40{ }^{\circ} \mathrm{C}$. Sonde 233557 and sonde 233559 met the test criteria derived for SC from the NFM and the USGS Techniques and Methods, book 1, chapter D3 (Wagner and others, 2006). Sonde 233558 exceeded the criteria when evaluated in a 100,000- $\mu$ S/cm standard. All three sondes exceeded the more stringent technical specifications for SC in one or more standards. All three sondes met both the USGS criteria for $\mathrm{pH}$ and for $\mathrm{DO}$ at room temperature and at the extended temperatures. Turbidity acceptance criterion was met by sonde 233557 in standards ranging from 10 to 3,000 NTU. Sonde 233558 met the USGS test criteria and the technical specifications except in the 3,000-NTU standard, where the percent difference from standard value was -13.23 percent. Sonde 233559 exceeded the USGS test criteria in the 10- and 20-NTU standards and exceeded the technical specifications in the 20-NTU standard.

Results of the field testing showed acceptable performance, with some caveats for extreme values for all parameters, and revealed that differences in data sample processing between sonde manufacturers may result in variances between the reported measurements when comparing one sonde to another. Variances in data processing would be more pronounced in dynamic site conditions, where extreme values could be missed with data averaging. The lack of a wiper on the DO sensor could prove problematic at sites with substantial biofouling.

\section{Acknowledgments}

The author wishes to thank Janice Fulford and the staff of the HIF Water Quality Servicing Laboratory for their help and support in this project. The author also wishes to thank Jack Gibs (USGS, retired) and Cherie Miller (USGS) for their contributions to this report.

\section{References Cited}

American Public Health Association, 1989, Standard methods for the examination of water and wastewater, 17th ed.: Washington, D.C., American Public Health Association.

Battino, Rubin, and Clever, H. Lawrence, 1966, The solubility of gases in liquids: Chemical Reviews, v. 66, no. 4, p. $395-463$. [Also available at http://dx.doi.org/10.1021/cr60242a003].

Gibs, Jacob, Wilde, F.D., and Heckathorn, H.A., 2007, Use of multiparameter instruments for routine field measurements (ver. 1.1): U.S. Geological Survey Techniques of Water-Resources Investigations, book 9, chap. A6, section 6.8, accessed January 4, 2013, at http://pubs.water.usgs.gov/twri9A/.

International Organization for Standardization (ISO), 1990, International Standard ISO 7027; Water quality—Determination of turbidity (2d ed.): ISO, 1990-04-15.

International Organization for Standardization (ISO), 2014, International Standard ISO 17289; Water quality—Determination of dissolved oxygen—Optical sensor method (1st ed.): ISO, 2014-07-01. 
OTT Hydromet, 2013a, Hydrolab HL4 sonde user manual (1st ed.): DOC026.97.80348, 162 p., accessed February 10, 2015, at http://www.ott.com/en-us/products/download/hydrolab-hl4-manual/

OTT Hydromet, 2013b, Hydrolab HL4 sensors user manual, $1^{\text {st }}$ ed.: DOC026.97.80349, 112 p., accessed February 10, 2015, at http://www.ott.com.

OTT Hydromet, 2013c, Hydrolab operating software manual, 1st ed., 34 p., accessed February 10, 2015, at http://www.ott.com/ en-us/products/download/hydrolab-hl4-sensor-manual/.

Wagner, R.J., Boulger, R.W., Jr., Oblinger, C.J., and Smith, B.A., 2006, Guidelines and standard procedures for continuous water-quality monitors — station operation, record computation, and data reporting: U.S. Geological Survey Techniques and Methods, book 1, chap. D3, 51 p., accessed June 1, 2017, at http://pubs.usgs.gov/tm/2006/tm1D3/.

For more information about this publication, contact

Chief, Hydrologic Instrumentation Facility

U.S. Geological Survey

Building 2101

Stennis Space Center, MS 39529

For additional information visit

https://water.usgs.gov/hif/

Publishing support provided by

Lafayette Publishing Service Center 



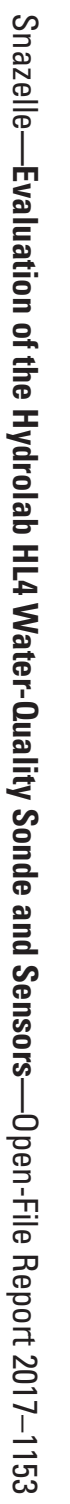

